\title{
Advantages of an Interdisciplinary Approach to the Sustainable Development of Two Scenarios in Bosnia and Herzegovina
}

\author{
Sanela Klaric ${ }^{1}$, Azra Korjenic ${ }^{2, *(1)}$, Jutta Hollands ${ }^{2}$ and Lamija Subasic ${ }^{3}$ \\ 1 Department of Architecture, Faculty of Engineering and Information Technologies, \\ International Burch University, 71000 Sarajevo, Bosnia and Herzegovina; sanela.klaric@ibu.edu.ba \\ 2 Institute of Material Technology, Building Physics, and Building Ecology, Research Unit of Ecological \\ Building Technologies, Vienna University of Technology, Karlsplatz 13/207-3, 1040 Vienna, Austria; \\ jutta.hollands@tuwien.ac.at \\ 3 Entrepreneurship and Innovation Center of the University of Zenica, 72000 Zenica, Bosnia and Herzegovina; \\ sklamija@hotmail.com \\ * Correspondence: azra.korjenic@tuwien.ac.at
}

Received: 10 May 2019; Accepted: 5 June 2019; Published: 13 June 2019

\begin{abstract}
Presently, almost all human activities (agriculture, transport, industry, construction sector, etc.) have an adverse impact on the environment. The construction sector in the EU alone accounts for a big part of the total energy consumption and emission of $\mathrm{CO}_{2}$. Two-thirds of the energy used in the construction sector in Europe goes to housing. As the number of residents grows, the requirements for new housing increase, causing an additional increase in energy consumption and new $\mathrm{CO}_{2}$ emissions for construction, maintenance, lighting, ventilation, cooling, and heating. Benefits of detailed planning of sustainable development of the construction sector are manifold. The most important benefits are sustainable use of resources, economic and social development of communities, increasing employment rates, improvements of living conditions and protection of the environment. Two scenarios for the development of an energy-efficient construction sector in Bosnia and Herzegovina with a focus on housing facilities are developed, in order to address the needs and benefits of detailed planning. Both scenarios analyze the effects on job creation, the impact of used construction materials on the environment and eco balance of local products. The difference in the solutions confirms the benefits of an interdisciplinary approach to the planning of sustainable systems so that not only technical, but also economic and social benefits can be evaluated thanks to the combination of methods used.
\end{abstract}

Keywords: sustainable development; sustainable housing; holistic approach; interdisciplinary planning; natural materials; primary energy; $\mathrm{CO}_{2}$ emission; strategic development

\section{Introduction}

\subsection{General Introduction}

Twenty years after the latest war, Bosnia and Herzegovina (BiH) still faces political, social, developmental and economic crises and hardly keeps step with the neighboring countries in terms of development. All reports on the progress of $\mathrm{BiH}$ towards the EU integration repeat the same recommendations that leaders of $\mathrm{BiH}$ have to find a common language regarding strategic development planning. On the other side, $\mathrm{BiH}$ is a rich country in terms of human and natural resources, and it can use all benefits of development by sustainable management of these natural resources and qualified workforce, on the basis of clean technology development on the territory of the whole country. 
A balanced development would create better life conditions, decrease population migrations and young people would be given a chance for life and future in $\mathrm{BiH}$.

In the EU strategy objectives are defined and the implementation of new clean technologies is strongly supported. There is a motivation to increase sustainable buildings and the use of natural materials. The criteria for the selection of ecological building materials concern not only the production, but also the use phase and the final disposal. The construction sector in the EU alone accounts for more than $45 \%$ of the total energy consumption and emission of $\mathrm{CO}_{2}$. Two-thirds of the energy used in the construction sector in Europe goes to housing [1]. In addition to energy consumption, this also includes the values for technical suitability and applicability, as well as the cost-benefit ratio and possible reuse and recycling [2]. Thus, it would be a good possibility for $\mathrm{BiH}$ to export their own natural resources to the EU. This would promote the domestic economy, create jobs and change the international perspective on $\mathrm{BiH}$ and its role in economy accompanied by an increase of the gross domestic product (GDP). Yet, there is no sufficient governmental support for clean and innovative technologies, which creates a big risk for investors. If the government would promote more initiatives or exempt them from taxes it would lead the decision-making process to clean technologies and a better direction, also in relation to the EU and the accordance with the strategic objectives of the EU [3].

This paper aims, at least in one part, to emphasize the importance of the integral strategic planning and recognition of opportunities for sustainable development through analyses of various resources and scenarios. It is hard to envisage a house-building trend for the next twenty-five years, which is a period concerned by both scenarios presented here, due to unexpected results of the economic crisis in $\mathrm{BiH}$ and, in line with it, a hardly determinable purchasing power of citizens in BiH. Led by the assumption of the faster accession process of $\mathrm{BiH}$ to the community of EU member states, a survey of standards, trends and requests for the housing sector in the $\mathrm{EU}$ and in $\mathrm{BiH}$ was used for both scenarios.

Globally, there is a trend of population increase in urban areas. The number of inhabitants, moving from rural areas to urban ones, grows and with this, housing issues in the cities need to be solved. The reasons for population migrations from these areas into more developed areas in $\mathrm{BiH}$ are under development of rural areas and the lack of employment opportunities. This phenomenon can also be observed in many other countries and regions around the world [4]. 1950 two thirds of the world's population lived in rural areas and only one third in urban areas. Caused by the urban migration process it is assumed that 2050 the division turns to the opposite and two thirds will live in urban areas. The division of the world's population in terms of urban settlement is very diverse. In industrial countries more people live in urban areas. In the year $2014,73 \%$ of the inhabitants in Europe and $81 \%$ in America lived in urban areas. At the same time, in order to lessen the mentioned population migration from rural to urban areas, the EU decided to allocate more than $35 \%$ [3] of its total budget and to direct these resources to rural areas development. Unfortunately, $\mathrm{BiH}$ government adopted the Strategy for rural development in BiH for the period between 2018-2021 in January 2018, after massive uncontrolled migrations caused by the war in 19ths, as well as with no strategy and no strong economy during the last twenty years [5]. The dilemma, and thus the great challenge, is to create an adequate number of living spaces for the population and to guarantee appropriate housing quality. The construction of sustainable buildings of high quality often contradicts the need for affordable housing in the short term [6].

Furthermore, a great number of cities in $\mathrm{BiH}$ has to manage their parts which previously were industrial zones, and as well, disorganized city parts in need of reconstruction and reorganization. Most cities in $\mathrm{BiH}$ have space to widen themselves in a planned manner, by using these abandoned zones which should be integrated into city life. New regulation plans for most cities in $\mathrm{BiH}$ need to be developed. These plans should contain the latest provisions regarding the environment and sustainable development, and also, they should respect and follow the methodologies for green sustainable cities development.

Further, climate changes lead to new housing conditions. Increase of external temperature, with long, hot periods during summer, creates the need for cooling a great number of flats in cities, 
and due to that many cooling devices have been installed, which consequently causes an increase in electrical power consumption and emission of greenhouse gases. On the other side, according to data of the Meteorological and Hydrological Service of the Federation of $\mathrm{BiH}$ [7], winters are longer and have a reduced number of sunny days. It causes an increase in heating energy consumption. This is why thermal insulation and functioning ventilation systems need to be developed more profoundly.

Most old buildings, and also some newly-built ones, do not comply with the energy efficiency requests and standards accepted in the EU, which leads to big energy losses and harmful gasses emission. In $\mathrm{BiH}$, some awareness-rising activities have already been done. They targeted not only investors but, also, users of spaces and their awareness regarding energy efficiency importance. Unfortunately, all efforts end with a simple adding a thicker layer of insulation, mostly of Styrofoam to facade and roof construction, and potentially, more quality windows with lower U-value are added, too. Only a few buildings have been constructed on the basis of a comprehensive approach, and in accordance with the valid standards on sustainable buildings in the EU and by using sustainable, local, natural materials. Elements of sustainable design are integral to the vernacular architecture that has evolved over time using local materials and technology emerging from ambient natural and cultural environment creating optimum relationships between people and their place. [8] Due to this, two scenarios have been developed that can help to argue for interdisciplinary strategic planning in the future in the energy efficiency sector of the civil construction in $\mathrm{BiH}$.

\subsection{Introduction of Two Scenarios: ECO and BAU}

Future planning decisions will be made taking into account life cycle costs and the results of the life cycle assessment. Only the simultaneous and interactive consideration of economic and ecological interrelations leads to solutions that can make a contribution to sustainable development [9]. A large number of certificates already exist for buildings dealing with the ecological assessment. These include, among many others, BREEAM, LEED and DGNB. Green buildings are not only an inevitable trend in the construction industry [10], but the choice of constructions and building materials also influences human health [11].

The impact of individual components on the environment depends to a large extent on the choice of construction material, but also on the choice of insulation material. An ideal building material is, thus, in a balanced relationship between ecological aspects and constructional requirements and must be chosen according to the external conditions. Numerous aspects influence the long-term sustainability of a building, including energy and resource consumption, socio-economic factors, as well as building design [12]. To do justice to this planning task, Reference [12] examined numerous design determinants for ecological building, which were further divided into six clusters, including environmental impacts, as well as social aspects and economy.

This paper takes up this complexity of the topic and combines two different assessment approaches for a region in which ecological building has not played a major role so far, but wooden construction has a long tradition. $\mathrm{BiH}$ is the most forested country in the Balkan area. Therefore, there is not only the tradition that the development of an ecological construction sector can be built on, but also a high potential to be used $[13,14]$.

In order to do justice to this complexity and to achieve as adequate an assessment as possible based on the three-pillar model of economic, social and ecological sustainability defined in the Brundtland Report [15], the two methods used were combined for the first time: On the one hand, the technical and material-related durability was analyzed, but the social and economic impacts for $\mathrm{BiH}$ were also included.

Sustainability in the construction industry has played a very subordinate or even no role at all in $\mathrm{BiH}$ to the present day. However, this development has great potential to counteract the high unemployment and rural depopulation and to enable economic growth and thus to find a solution as demanded in Reference [16]. 
Häkkinen [17] points out that the type of construction in urban areas plays a decisive role in the sustainable development of cities. The sustainable urban construction-related indicators, such as environmental impacts of the building; health and comfort, quality of building; availability of housing and buildings; full exploitation of new technological challenges; the age of building stock, activities in refurbishment and renovation are analyzed. A selected combination of these indicators will also be used in the investigations in this article for the $\mathrm{BiH}$ site.

The assessment system for sustainable construction published by the German government in Germany also clearly states that sustainable construction is often understood to mean energy-efficient construction in particular, but this is not sufficient as energy efficiency is only one part of sustainability and financial effects must also be considered [18]. This is also the approach taken in this article. In comparison to the German studies, however, the existing database in Germany is not available in $\mathrm{BiH}$. To this end, attention must be drawn to sustainable construction, further investigations must be carried out and a similar platform for $\mathrm{BiH}$ can then be made possible in the further course of the research. This approach of further creation of acceptance for sustainable building and the associated further development of evaluation methods depending on the location is also explained by Reference [19]. In their study of sustainable development in the Western Balkans, they also come to the conclusion that regional cooperation, as well as international partnerships between municipalities are of significant importance. The dependence of the location of the consideration for the assessment of sustainability is also mentioned by Reference [20] and the associated challenge that there is no single method and solution for sustainable buildings and therefore the further development of these is constantly necessary.

Following on from these findings, methods were newly combined within the framework of carried out research for the $\mathrm{BiH}$ site in order to achieve both a further step for the sustainable development of the construction sector based on all three pillars and thus to enable the basis for decisions, further development of the methods for $\mathrm{BiH}$ and the creation of a larger database.

Two different scenarios were examined in order to demonstrate the differences in conventional construction and the potential of ecological construction. The first scenario BAU (common practices-business as usual) assumes a continuation of construction sector development, according to current standards, trends and requests, with a static development without any big changes and innovation in the construction practice. While the second scenario ECO (ecologically oriented) assumes a continuation of construction sector development, in accordance with the most contemporary standards, trends and requests, with dynamic development and envisioned changes regarding sustainable innovative development, which will primarily use local natural resources for construction. The impact of bio-based houses in comparison to conventional concrete houses in passive house standards was already researched by Krasny et al. [21] with the result of big differences concerning the Global Warming Potential (GWP) and the costs. Results obtained by comparison of the advantages and disadvantages of the two scenarios can contribute to a strategic approach to planning and programming of sustainable housing construction sector in the future.

The civil construction sector is an economic branch that includes a whole range of activities and connects a great part of other economic branches which support it, as for example production and processing of construction material and building elements, electrical-power industry, mechanical elements production industry, as well, industry/production of materials that are not exclusively applicable only in the civil construction sector. The supply chain of the construction sector includes not only the value chain of the construction industry also includes numerous other areas. The economic impact of these linkages was examined in detail for Germany in Reference [22] with different observation limits. The authors of the report divide the construction sector into an inner core (construction and planning), an outer core (sectors with construction-relevant services) and a peripheral area (rest) and come to the conclusion that 60 percent of the production value of the value chain "construction and planning" arises in sectors that do not directly belong to the inner core. Vrijhoef and Koskela [23] also state in their studies on supply chain management in the construction sector that this management 
plays an important role in relation to waste production in the construction sector. Therefore, the analysis of these two scenarios will give important guidelines for future sustainable development of the civil construction sector with accompanied industry and services in $\mathrm{BiH}$.

Within this research, two scenarios will be developed on the basis of analyses of three indicators of success with existing tools and calculation methods. In the end, the results of the research will be presented, and as well, a comparison of the advantages and disadvantages of obtained results will be given, and at the end, recommendations for further research and development are presented.

In the course of developing two different scenarios for the housing sector, environmental, social and economic impacts on two developmental options of future construction practice will be researched. Furthermore, obtained indicators will be compared and new developmental opportunities will be suggested. The third scenario, which would represent a development with partial changes, was not taken into consideration in this research, in order to point out the importance of the integral approach to comprehensive planning of housing construction sector development in the future.

It has to be pointed out, that the challenges of investing in alternative technologies are huge. There is a risk of investing in technology that will not bring any bigger profit in the short-term period, comparing to what the recent practice has already shown. Also, it should be emphasized this is a long-term process and economic-financial results in a long-term sense should be considered. Launching any new technology asks for investments in researches, registration of (or obtaining a patent for) a product, opening new plants, which represents an additional financial burden at the beginning.

In the case of an innovative approach to material and its presentation on the market should be careful and realistic. Any innovation needs time for clients and consumers to acquaint with it, and to start using it. When a diagram of acceptance of an innovation is considered, it can be seen, in the beginning, there is only a small number of enthusiasts who support the innovation and it takes time for a larger number of others, who are courageous enough, to join this small group and support the innovation. It is necessary to have a number of practical examples and experience, for innovation to be accepted by a larger number of future users.

Figure 1 shows time span and attitudes towards innovations in practice. It can be seen it is needed to invest time for innovation to be accepted by the majority. Until investors, who buy their flats or houses, do not reach the level of awareness on responsible and sustainable housing, on energy efficiency needs and healthy natural materials, examples of green objects, made of natural materials, will remain only rare examples. When users' requests enlarge and when more examples, proving the claims of various expertise occur, then the demand for sustainable homes will increase [24].

The total gain and results should not be considered only on the basis of financial aspect, because this paper elaborates on all possible savings and advantages-from the decreased energy consumption, $\mathrm{CO}_{2}$ emission reduction, having healthier lives, turning back to nature and natural resources through the use of natural materials, which—after their natural life span is over-go back to nature in the same or similar shape. 


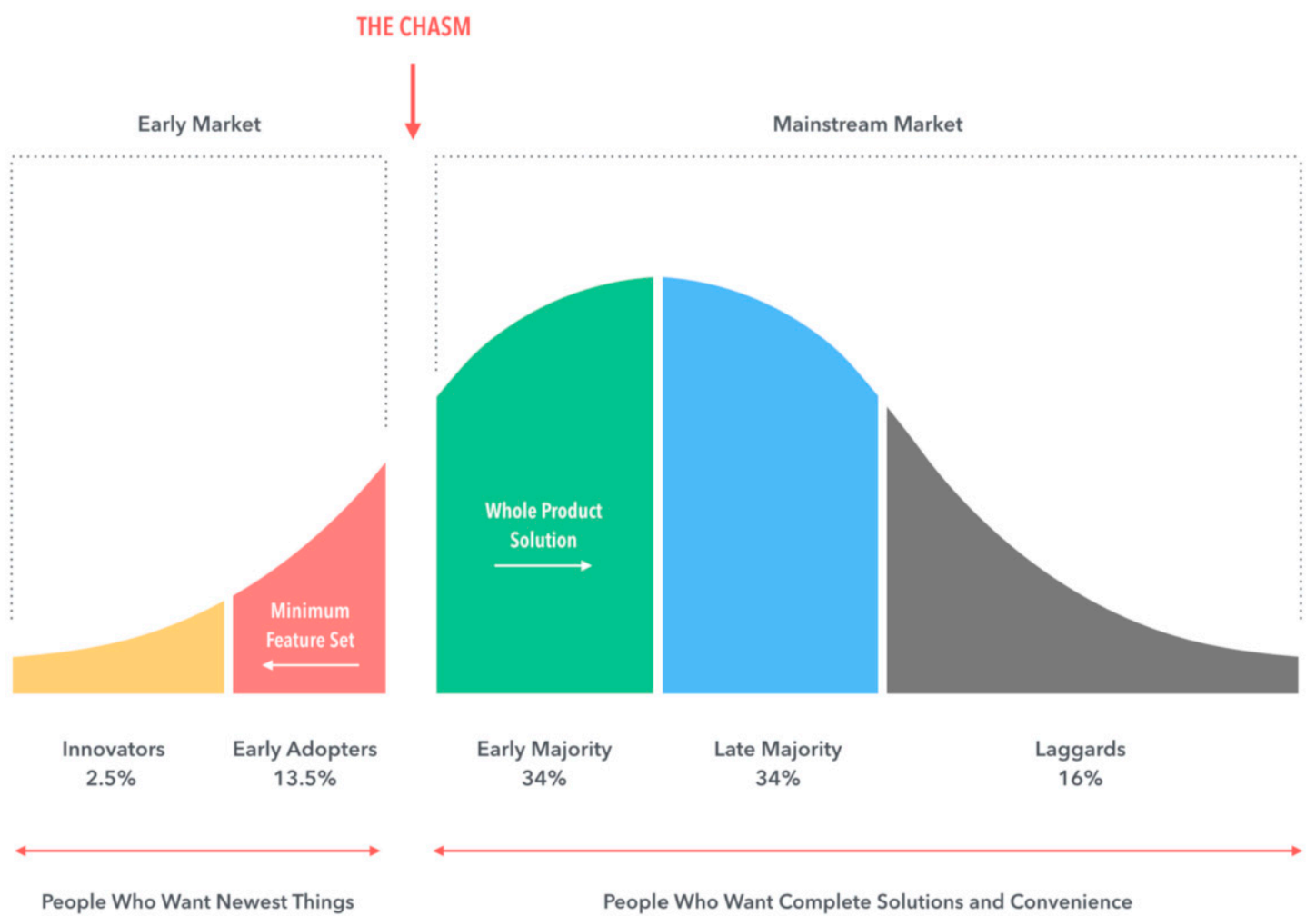

Figure 1. Acceptance of innovation in practice [11].

\section{Methodology}

Assessments of the impact of both scenarios use three indicators of success regarding the construction sector development:

- Number of new workplaces (by using the method of following trends and assumptions of development);

- Impact of used construction materials on the environment (by using the comparative method);

- Eco-balance of local products (by using a method of analysis of sustainability assessment indicators and HAM3D calculation).

Both scenarios are done by using the most contemporary, and currently available, developed methodologies and tools. The greatest challenge was a very limited base of available data and statistics. Some data were obtained via interviews and market research, respectively, while other information was gathered from the Agency for statistics in $\mathrm{BiH}$. Official data on climate do not exist in $\mathrm{BiH}$, which is why climate data for the City of Vienna were used for software calculation of these scenarios.

The time span for both scenarios is 25 years, i.e., the period from 2015 to 2040, while this period represents an optimal long-term development perspective.

The two chosen scenarios are not the only two possible scenarios: They present two feasible scenarios of construction sector development in $\mathrm{BiH}$ until 2040. The main intention of this paper, and its focus on these two scenarios, is to start in the future a meaningful discussion that should lead to optimal solutions for construction sector development in $\mathrm{BiH}$.

Several rating models were taken, because one model would have provided a reductionist perspective. For example, one model would merely respect the labor market, another only environmental impact. Several rating models in combination contain so many influences that in the end there is a good overview of the advantages and disadvantages of the building construction. Indicators of success. The model as mentioned in Reference [25] offers an indicator-based sustainability assessment for affordable housing construction technologies has been used to compare two prefabricated constructions 
including many economical and sustainable impacts, as well as a great variation of indicators in regards the sustainable and responsible building constructions. The other method considered makes precise calculations according to the thermal properties of the constructions and concerning humidity in the building construction. Addition to those two the heat transmission coefficient, as well as the potential of global warming of building constructions is calculated to examine the importance of the energy efficiency of a building and further on for the environment.

Indicators of success are individually presented and explained in the following, along with the way they were observed and checked.

\subsection{Number of New Workplaces}

The civil construction sector has its specific features, is strictly regulated and differs greatly from other sectors. It is a heterogeneous and fragmented sector, based upon a great number of various professions. It has been defined by EU NACE (NACE (Classification codes), a European industry standard classification system, was presented in 1970. In 1990, a revised version was adopted, and it stated, "NACE stands for 'Nomenclature Generale des Activites Economiques dans I'Union Europeenne' (General Name for Economic Activities in the European Union)". Currently is valid a version accepted by the United Nations in 2008: "International Standard Industrial Classification of all economic activities" (ISIC)) 1 Mode, 1 sector classification, including the following sub-sectors:

1. Suppliers of construction products and components (including local production);

2. Preparation of construction site, the building of fully completed facilities, the building of plants, finishing and renting the construction machines;

3. Professional services (making designs and providing consultations) [26].

On the basis of the official sector classification, the analysis of the increase of new workplaces in the construction sector and its parts in the period until 2040 for both assumed scenarios will be done in the following.

\subsection{Impact of Used Construction Materials on Environment}

Although, according to NACE codes, construction materials do not belong to the construction sector classification, for the purpose of this analysis, construction material will be considered as a part of construction sector, especially in the part of ECO scenario, as this scenario puts a focus on the development of the construction sector along with maximal use of available local natural materials.

Tools and methodologies for calculation of the impact of a particular construction material, or construction sector product, have been developed in the EU and worldwide. As there is no data for $\mathrm{BiH}$ in this part, data from the State catalogue for civil construction of Austria will be used. There are calculated impacts for every material or product, considering the mentioned tools and methodologies for the impact these materials have in Austria, but for this research it will be used as guide values for $\mathrm{BiH}$ as there is no other opportunity for this data quality for this case from $\mathrm{BiH}$. Further research can be carried out into the extent to which other databases outside $\mathrm{BiH}$, but more geographically or production-specifically close to $\mathrm{BiH}$, have an influence on the results.

\subsection{Eco-Balance of Local Products}

For the part on eco-balance of local products the already developed method of analysis of sustainability assessment indicators and HAM3D simulation will be used for both scenarios. The first method was developed at ETH Zurich, while the simulation software HAM3D was developed at the Technical University of Vienna (TUW). Their combination gives a more precise way of understanding the impact of construction technology on the environment, way of comparing advantages and disadvantages, and a more realistic analysis of strategic commitments.

The chosen methods are very simple and easy to understand compared to some other methods like the multi criteria decision making methods ELECTRE or MAUT [27]. 
The first method includes many economical and sustainable impacts and it provides a great variation of indicators. It respects the financial side from the prime cost to the maintenance. It considers the origin of the resources, as well as the time and the complexity of the installation, the infrastructure and the potential of recycling.

The second method makes precise calculations according to the thermal system of constructions and concerning humidity by using HAM3D. The heat transmission coefficient, as well as the potential of global warming of building constructions is calculated which is important for the energy efficiency of a building and further on for the environment.

\section{Investigation of Scenarios}

BAU Scenario-BAU scenario assumes a continuation of construction sector development in accordance with the current standards and requests with no big changes.

The most newly built objects for individual and collective housing in $\mathrm{BiH}$ are mostly made of materials of poor quality and low price that are mainly produced out of BiH. During import, these materials do not have to comply with any strict control. The most materials for construction, currently used, demand a high percentage of primary energy consumption and high emission of $\mathrm{CO}_{2}$ in the course of production, transport, installation and use. These materials are not recycled, i.e., recycling is possible, but the costs of it are very high and technology is missing in BiH. Quality of living conditions in the most newly built buildings is very questionable due to wrong orientation, materialization or position of a building on the lot. A guiding idea of those who invest in these new houses is profit-not the comfort of future users, or care for the environment.

Materials, most often used in the construction practice for houses are: Reinforced concrete, concrete blocks, baked bricks, cement plaster, Rigips, Styrofoam, glass wool, acrylic facades, etc. An example for this way of construction is given in Figure 2.

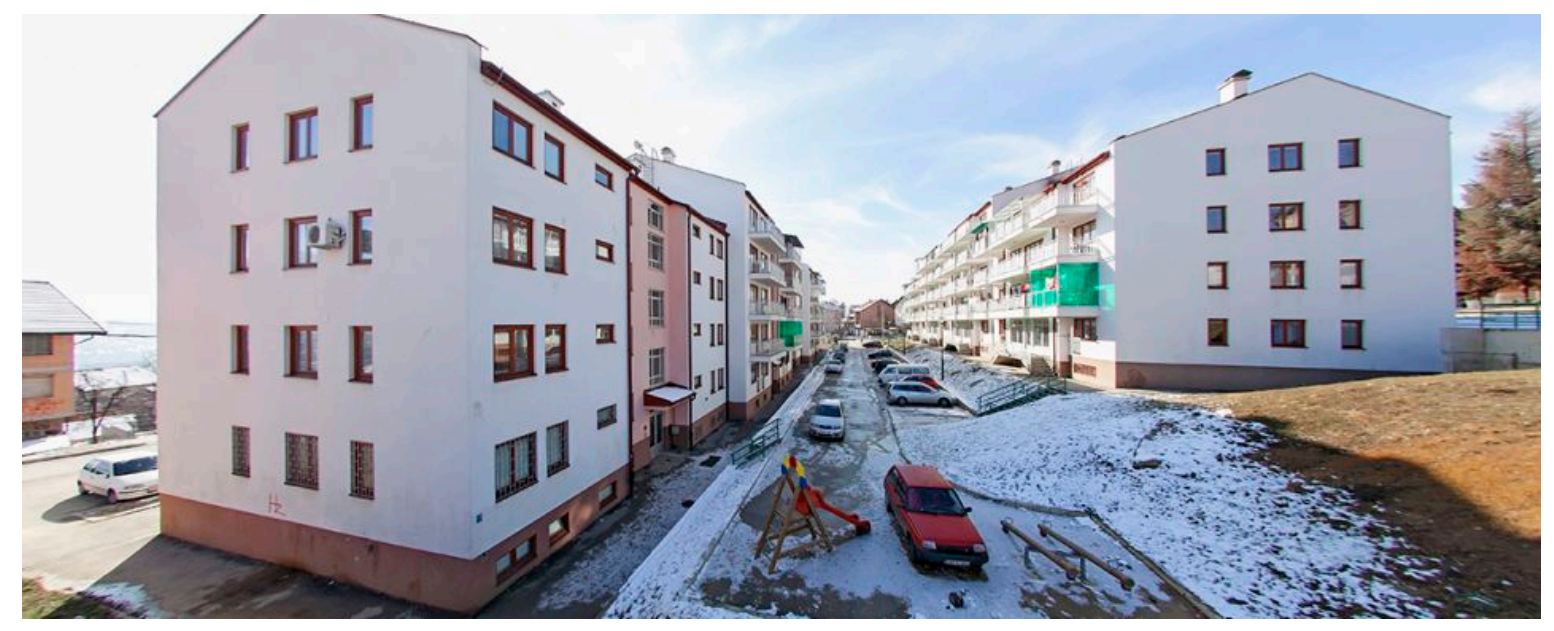

Figure 2. New residential building, settlement Pofalići, Sarajevo [28].

ECO Scenario-ECO scenario assumes a continuation of construction sector development, in accordance with the most contemporary standards and requests, with dynamic development and targeted changes in direction of sustainable innovative development, with the use of local natural resources for construction. Changes in construction practice would be clearly visible, users' life conditions would have more quality and the overall impact on the environment would be significantly favorable.

It is assumed that in this scenario the majority of newly built objects of individual and collective housing will be done with the most quality, locally produced, materials with affordable prices. These natural materials do not have a high percentage of primary energy consumption and have no high emission of $\mathrm{CO}_{2}$ during their production, transport, installation and use, since they are 
produced locally. The majority of local materials, which are used in this scenario, currently represent ecological waste, and their sustainable disposal would additionally bring to environment protection. Forest management in $\mathrm{BiH}$ would be done in accordance with the strict EU standards and wood production would be certified and sustainable. All materials would be recyclable or reused. Recycling itself does not ask for high energy consumption nor it causes additional significant pollution. Most natural materials, at the end of their life cycle, turn into compost and serve as fertilizer or additional food to agricultural soil.

Living conditions in these buildings are very healthy, i.e., buildings made of natural materials breath and create a very comfortable atmosphere for users. Constructions can be very flexible, and they allow making changes without any damages to neighboring parts and modules, and given that, they reduce costs of maintenance and reconstruction.

Materials most often used in the contemporary sustainable construction practice for building housing objects of prefabricated elements, are: Wood, sheep wool, straw, plaster, clay, lime.

\subsection{Number of New Workplaces for BAU and ECO Scenarios}

Within the BAU scenario, under the assumption of an increasing need for new housing units in $\mathrm{BiH}$, as it has been already elaborated, an increase of new workplaces can be expected. In the first nine months of 2018, the number of completed dwellings was about 1.537 which represents a nominal increase of $6.0 \%$ in comparison to the same period in 2017. The average number of workers employed on construction sites by legal entities in 2016 was about 19.650 and represents an increase of $7.2 \%$ compared to 2015. Moreover, the number of hours worked on construction sites increased by $7.2 \%$ compared to the previous year. In 2017, $19.969 \mathrm{~h}$ were worked in the construction sector. This represents an increase of $1.6 \%$ compared to 2016, while the number of hours worked on construction sites increased by $4.7 \%$ between 2016 and 2017. In the sector of suppliers of construction products and components an increase of demand for the workforce can be expected, predominantly for persons with finished high school education. The existing construction industry plants, under assumption of developing and spreading (concrete plants, cement plants, plants for aluminum production, for glass and facades and plastic processing) will, also, need new workforce with high school education completed, and as well, those with lower levels of education, and, to a lesser degree, will be needed those who completed higher education.

At the construction sites can also be expected an increase of demands for the workforce with high school education completed, and as well, those with lower levels of education, and-to a lesser degree- - those who graduated from higher education. A similar situation can be expected in companies for construction machines renting.

In the sector of professional services (designing and consulting), an increase of requests for new projects is expected, and in line with it, an increase of requests for workplaces for a person who have higher education degrees.

Companies that produce prefabricated houses currently in their plants produce elements with U-value adjusted to the EU standards. Demands for those houses in BiH are sporadic. Export of these construction elements has been registered. Beside the local wood, used for production from the registered sustainable sources, most other wall elements are not produced locally in $\mathrm{BiH}$, but imported from abroad. Even if the number of requests for export or building of these objects in $\mathrm{BiH}$ increases, new workplaces in the country can only be expected in the local wood industry, i.e., sawmills, and a lesser number in the industry of prefabricated houses and local plants for Styrofoam production, and mostly workers with high school completed will be wanted, or those with lower levels of education. Most other wall parts will, still, be imported and no new employments will occur (in the production of mentioned elements), while support by local production still is missing (or be negligible).

It can be concluded that significant requests for opening new workplaces will occur at the construction sites and in traditional construction industry and construction materials production, and a lesser number of requests will be in the sector of professional services for designing and 
consulting. Simultaneously, there will be no significant requests for new workplaces in scientific institutions, while, in accordance with this scenario, the majority of construction materials will be imported, i.e., no new industrial plants for innovative clean technologies, which needs the support of research centers, will be opened.

Within the ECO scenario, major changes would happen in construction practice that would bring a great number of innovations in clean sustainable technologies in $\mathrm{BiH}$. Potential for opening new small enterprises, which will start producing construction elements from natural local resources, is huge. An intention to have all parts of these constructions produced in $\mathrm{BiH}$ will result in opening many small plants throughout $\mathrm{BiH}$, especially in its currently underdeveloped rural areas, which additionally supports the development of a significant sector of suppliers and producers of construction materials. Establishment of these plants undoubtedly leads to an increased demand for new workplaces, primarily for non-qualified workforce and workers with high school education, and as well, a smaller number of highly educated employees, who are necessary for managing these plants.

Besides adjusting the old plants for prefabricated wood houses production, this scenario would cause opening new plants for clean technologies which until now have not been present in $\mathrm{BiH}$. Innovative products from these plants would be used for prefabricated houses production, and as well, for other ecological types of building. This approach will help the overall economic development of $\mathrm{BiH}$, especially the development of rural areas in $\mathrm{BiH}$. Simultaneously, migrations of young people from rural to urban areas would be additionally balanced with the rural areas' development vision and new clean technologies.

In the sector of professional services, designing and consulting, it is assumed an increase of requests for new projects will happen, and in line with it, the requests for new workplaces for highly educated persons will, also, occur.

A comprehensive approach to designing housing objects, that implies sustainability and energy saving, and $\mathrm{CO}_{2}$ emission reduction, will demand an additional inclusion of experts from other fields (chemistry, physics, psychology, alternative energy, etc.), which will increase demand for new workplaces for highly educated persons in this important sector.

Innovative approaches to construction elements production, based on local materials use, which apply modern practices, will manage to establish good, and necessary, cooperation between industry and universities, and institutes of research and development, respectively. This cooperation, which supports innovations in clean technologies, will demand new workplaces for research work, i.e., workplaces for highly educated persons in all fields of education and science. Also, this approach will answer many questions of the local construction industry and open some new questions, suitable to serve as topics of new scientific studies.

A small increase of a number of new workplaces is expected in the conventional construction practices, dealing with preparatory works for making foundation (concrete plants, cement plants), where will be needed mostly those who have a high school diploma. In this part, too, can be used an innovative approach to building foundations for smaller buildings, by taking into consideration methods used in the traditional way of building, but with the use of local stone and locally produced hydraulic lime.

ECO scenario assumes mass building with prefabricated elements produced locally in the current and newly-opened production plants. Additionally, the increased export of these sustainable constructions to the EU and the USA markets is assumed, especially since these countries have committed till 2020 to support prefabricated building from natural materials, with the main goal of enlarging the part of these buildings in the total number of newly-built objects for at least $10 \%$.

Locally produced prefabricated construction, out of the reason of lowered production and installation prices, as a direct result of lower labor price and lower material price, can be competitive given the mentioned requests. Prices of these products are also competitive in the local market.

It is necessary to emphasize that a great impact of transport on the environment has to be considered, as well. Therefore, a choice of transport mode has to be adjusted to both requests of 
sustainability and environment protection, and use of railway transport, as the cleanest mode, has to be used to the maximum. This request can instigate reconstruction of the current railroad infrastructure in $\mathrm{BiH}$, which additionally will open new workplaces in clean, ecologically balanced, transport sector.

It can be concluded that ECO scenario leads to a great number of workplaces in clean industry and sustainable construction industry of $\mathrm{BiH}$, and to the overall economic and social development of the state in all its regions.

\subsection{Impact of Used Construction Materials on Environment for the BAU Scenario and the ECO Scenario}

BAU Scenario-Materials used until now and the construction practices in $\mathrm{BiH}$ have a great impact on the environment. The current practices do not pay attention to new standards and changes that advocate for sustainable clean building and use of natural local materials. Materials, that have been mostly used, to a great extent need a lot of primary energy, have a high percentage of $\mathrm{CO}_{2}$ emission, cannot be recycled or recycling is very expensive, can be toxic and harmful to human health, and they are not flexible.

ECO Scenario-ECO is an approach to construction practice and innovations, that would introduce the use of natural materials, which are currently environmental waste in $\mathrm{BiH}$ and by this would greatly lessen the current harmful impacts of the construction sector on the environment. Natural, local materials are used innovatively to decrease primary energy consumption and $\mathrm{CO}_{2}$ emission. In addition to it, construction materials, produced of natural, local materials, are recyclable, are not toxic or harmful to human health and they enable modelling and flexibility.

Values which impact the environment due to the use of different materials, will be analyzed in both scenarios, and are taken from the official catalogue of construction materials in the state of Austria, "Baubook" [29].

The manufacturing process of a product is different in every country, so the data from $\mathrm{BiH}$ would variate from the data of Austria. But here the main focus is on the comparison of the advantages and disadvantages of construction methods and their effects on $\mathrm{BiH}$. In a further step, it will be useful to repeat this investigation with data for $\mathrm{BiH}$, once they have been collected and to compare the results.

In order to make comparison easier for these materials, the values of potential global warming will be given. The table clearly shows the construction materials, currently used for building, have huge negative impacts on the environment, seen in the stated values of potential global warming in Table 1. On the basis of comparison of potential global warming values, where natural materials (e.g., wood and straw) have negative values of impact on the environment, contrary to construction materials used in conventional building practice, can be concluded that building of prefabricated houses has a lesser impact on the environment.

Table 1. Values of potential global warming for materials in ECO and BAU construction [29].

\begin{tabular}{ccc}
\hline Material & $\begin{array}{c}\text { GWP } \\
{[\mathbf{k g ~ C O} \mathbf{~ e q} . / \mathbf{k g}]}\end{array}$ & Material Used in Scenario \\
\hline Sheep wool & 0.537 & ECO \\
Straw & -1.25 & ECO \\
Insulation panels of wood fibres & -0.183 & ECO \\
Insulation plates of straw & -1.59 & ECO \\
Wood & -1.26 & ECO \\
Oriented strand board (OSB) & -1.051 & ECO \\
Glass wool & 2.454 & BAU \\
Mineral wool & 1.6 & BAU \\
Baked bricks & 0.0951 & BAU \\
Plaster-cardboard & 0.176 & BAU \\
Polystyrol & 0.209 & BAU \\
\hline
\end{tabular}


Regardless of the stated negative values of natural materials on the environment, both types of building are used with materials which mostly are not produced locally and spend a high percentage of energy on transport, production, installation and emit a high level of harmful gases. The most materials used in practice have a high environmental impact also because they are not or hardly recyclable and not flexible. According to the BAU scenario, with the current conventional practices, the construction sector will heavily and badly impact the environment. It can be concluded the ECO scenario secures to the maximum a decrease of global warming impact in very high values, on the basis of very good features of local natural materials, which can address all requests of sustainable development.

\subsection{Eco-Balance of Local Products for the BAU and the ECO Scenario}

Two research methods were used to determine the indicator of success "eco-balance of local products". They were applied to both scenarios, which were directly compared.

In further research, two samples of prefabricated wall construction, different in their materialization, were used. For the first construction, the prefabricated wall, currently produced in $\mathrm{BiH}$ was used. For the second construction, the modern prefabricated wall, which has straw as material for thermal-insulation, was used.

It should be emphasized that these construction samples have similar U-values, which groups them among materials that can be used for passive houses building.

\subsubsection{Method 1}

The first method, used for testing the indicators for the assessment of sustainability regarding the available technologies in house-building, was a method developed by Wallbaum et al. [25] The method consists of many structured construction assessments via elaborated tabular analyses and grading for the purpose of establishing the needed indicators. The established indicators relate to: rice of making constructions, degree of production complexity and construction installation complexity, time frame and level of prefabrication, economic scale (i.e., advantage of mass production), duration, maintenance costs, modulation and flexibility, creation of local values with the use of local potential and development of local communities, level of simplicity and costs in cases of connecting to local infrastructure and maintenance services, and recyclability or reuse. Afterwards, the established indicators were compared to challenges of tested technology: Lack of local resources, lack of sufficient or safe funds, lack of time given the urgency of the request, lack of skilled workforce, quality control, dissipation due to inefficiency, lack of added value of creativity, quality and location.

For selected materials and constructions, the indicator of the value of material insulation features is added, i.e., a construction as a whole, assessed according to its U-coefficient. U-coefficient or material heat conductivity is the quantity of heat conducted per material surface unit measured by the temperature difference between the internal and external environment $\left(\mathrm{W} / \mathrm{m}^{2} \mathrm{~K}\right)$.

After this research, which compared the stated indicators with the challenges of house-building, an assessment of sustainability regarding the available technologies in house-building is obtained, which is chosen as a sample for the BAU and the ECO scenarios.

This methodology for sustainability assessment of available technologies consists of a range of structured assessments of construction on the basis of tabular analyses and grading, in order to obtain needed indicators.

This method investigates two selected prefabricated wood constructions, which represent technology currently used in $\mathrm{BiH}$ as the BAU construction and the innovative construction which is currently used in the EU as the ECO construction:

BAU Construction: Standard prefabricated wall, currently produced in BiH (Krivaja Factory, in Zavidovići) [17].

ECO Construction: Prefabricated wall, containing straw in its thermal-insulation part (Mod Cell Homes, the United Kingdom) [30]. 
Table 2 shows the summed data on the observed constructions, compared and analyzed by the first method.

Table 2. Summed data on the observed constructions.

\begin{tabular}{|c|c|c|}
\hline Title of Technology & $\begin{array}{l}\text { BAU Construction } \\
\text { Prefabricated Wood Wall }\end{array}$ & $\begin{array}{c}\text { ECO Construction } \\
\text { Prefabricated Wood Wall }\end{array}$ \\
\hline Data and country of origin & Krivaja Catalogue, $\mathrm{BiH}[31]$ & Mod Cell Homes Catalogue, UK [30] \\
\hline \multirow[b]{2}{*}{$\begin{array}{l}\text { 3D presentation from } \\
\text { producer }\end{array}$} & & Modcell' Core + \\
\hline & & $=0$ \\
\hline Category of building & Residential house & Residential house \\
\hline Dimension of building & $100 \mathrm{~m}^{2}$ & $100 \mathrm{~m}^{2}$ \\
\hline Environment where it is built & Urban & Urban \\
\hline Construction & Prefabricated walls and roof & Prefabricated walls and roof \\
\hline Price per $\mathrm{m}^{2}$ & $\begin{array}{c}44.20 €\left(86.64 \mathrm{KM} / \mathrm{m}^{2}\right) \\
\text { Price of material, without the price of } \\
\text { making and installing }\end{array}$ & $\begin{array}{c}34.53 €\left(67.67 \mathrm{KM} / \mathrm{m}^{2}\right)^{*} \\
\text { Price of material, without the price of } \\
\text { making and installing }\end{array}$ \\
\hline Building process & Dry building process & Dry building process \\
\hline needed building time & One week & One week \\
\hline $\begin{array}{l}\text { Economic scale/mass } \\
\text { production }\end{array}$ & $\begin{array}{l}\text { In the case of mass production, a great } \\
\text { possibility for a price decrease }\end{array}$ & $\begin{array}{c}\text { In the case of mass production, a great } \\
\text { possibility for a price decrease }\end{array}$ \\
\hline Durability & Permanent object & Permanent object \\
\hline Maintenance requests & Minimum & Minimum \\
\hline Modulation/Flexibility & $\begin{array}{l}\text { A great possibility of flexibility and } \\
\text { modulation }\end{array}$ & $\begin{array}{l}\text { A great possibility of flexibility and } \\
\text { modulation }\end{array}$ \\
\hline $\begin{array}{l}\text { Potential for recycling and } \\
\text { reusing }\end{array}$ & $\begin{array}{l}\text { Wood, wood products, plaster cardboard: } \\
\text { A high percentage of recycling and reusing } \\
\text { Styrofoam and mineral wool: Cannot be } \\
\text { recycled or recycling is expensive }\end{array}$ & $\begin{array}{l}\text { All parts of the prefabricated wall: } \\
\text { High value of recycling }\end{array}$ \\
\hline Level of using local resources & $\begin{array}{l}\text { Except wood, all other parts of the wall } \\
\text { currently are imported. }\end{array}$ & $\begin{array}{l}\text { All parts of the wall can be obtained } \\
\text { locally, except OSBs and insulation } \\
\text { boards of wood fibres. For these parts } \\
\text { of the wall, local production has been } \\
\text { recommended, while local resources } \\
\text { are available, and also, markets that } \\
\text { would be connected to the production } \\
\text { of prefabricated houses. }\end{array}$ \\
\hline $\begin{array}{l}\text { Presence of this way of } \\
\text { building }\end{array}$ & $\begin{array}{l}\text { At the moment, prefabricated building in } \\
\text { BiH has a low presence. } \\
\text { Promotion is recommended and it should } \\
\text { include all stakeholders. }\end{array}$ & $\begin{array}{l}\text { At the moment, prefabricated } \\
\text { building in BiH has a low presence. } \\
\text { Promotion is recommended and it } \\
\text { should include all stakeholders. }\end{array}$ \\
\hline Proximity of public services & $\begin{array}{l}\text { Urban parts of the city have developed } \\
\text { infrastructure, to which the prefabricated } \\
\text { building can be easily connected. }\end{array}$ & $\begin{array}{l}\text { Urban parts of the city have } \\
\text { developed infrastructure, to which the } \\
\text { prefabricated building can be easily } \\
\text { connected. }\end{array}$ \\
\hline U-value & $0.10 \mathrm{~W} / \mathrm{m}^{2} \mathrm{~K}$ & $0.11 \mathrm{~W} / \mathrm{m}^{2} \mathrm{~K}$ \\
\hline
\end{tabular}

*: Total price calculation is done according to market prices in BiH in July 2014 with exchange rate $1 €$ to $1.96 \mathrm{KM}(2014)$. 
(1) Initial Price of Construction

The given catalogue prices cannot be compared due to great differences between the prices of material and labor in the UK and BiH. Out of that reason, the prices in Table 3 present calculation of prices of the wall elements, reached by considering prices of elements and materials on the market of $\mathrm{BIH}$, and with no labor price included.

Table 3. Initial price of construction $\left[E U R / \mathrm{m}^{2}\right]$.

\begin{tabular}{cccc}
\hline Price per $\mathbf{~ m}^{\mathbf{2}}$ & Number of Points & BAU Construction & ECO Construction \\
\hline$<\mathbf{2 0} €$ & 10 & & \\
$<\mathbf{3 0} €$ & 8 & 6.3 & 6.9 \\
$<\mathbf{5 0} €$ & 6 & & \\
$<\mathbf{7 0} €$ & 4 & & \\
$>\mathbf{9 0} \boldsymbol{€}$ & 2 & & \\
\hline
\end{tabular}

(2) Degree of Production and Installation Complexity

The same degree of production process and installation complexity is assumed for both prefabricated constructions. The corresponding values are given in Table 4. Also, it is assumed the available technologies and tools will be used, and as well, materials which do not need any special processing or protection in the course of work. In addition, $\mathrm{BiH}$ has workers who can do this job, complying with all requests of making and installing these constructions.

Table 4. Degree of production and installation complexity.

\begin{tabular}{|c|c|c|c|}
\hline $\begin{array}{c}\text { The Degree of Production Process Complexity and } \\
\text { Installation Complexity }\end{array}$ & $\begin{array}{l}\text { Number } \\
\text { of Points }\end{array}$ & $\begin{array}{c}\text { BAU } \\
\text { Construction }\end{array}$ & $\begin{array}{c}\text { ECO } \\
\text { Construction }\end{array}$ \\
\hline $\begin{array}{l}\text { Physical workforce with no special skills, the current } \\
\text { workforce at the local site, familiar with the tradition of this } \\
\text { kind of building. Tools for building are available. }\end{array}$ & 10 & 10 & 10 \\
\hline $\begin{array}{l}\text { Non-skilled workforce, in need of two-week training to } \\
\text { acquire relevant skills, current workforce available at } \\
\text { the location. }\end{array}$ & 8 & & \\
\hline $\begin{array}{l}\text { Non-skilled workforce, in need of intensive education } \\
\text { (for several weeks), skilled workforce. }\end{array}$ & 6 & & \\
\hline Special skills and tools needed. & 4 & & \\
\hline Highly sophisticated skills and very precise tools needed. & 2 & & \\
\hline Information not available & 0 & & \\
\hline
\end{tabular}

(3) Time Frame, Level of Prefabrication

It is assumed, time frame and level of prefabrication for both constructions are similar, due to similar technologies. The values for this are shown in Table 5.

Table 5. Time frame, level of prefabrication.

\begin{tabular}{cccc}
\hline Time Frame, Level of Prefabrication & Number of Points & BAU Construction & ECO Construction \\
\hline Installing one element $<1$ day & 10 & 10 & 10 \\
Installing one element $1-3$ days & 8 & & \\
Installing one element $<1$ week & 6 & \\
Installing one element $<2$ weeks & 4 & \\
Installing one element $>2$ weeks & 2 & \\
Information not available & 0 & \\
\hline
\end{tabular}


(4) Economy of Scale/Advantage of Mass Production

It is assumed that mass production of ECO construction enhances a greater economic development of $\mathrm{BiH}$ and, also, it enlarges the number of workplaces and reduces the final price of the product on the market, which makes a product more competitive. The results are shown in Table 6 . This insight and assessment comes from the numerous interviews held in $\mathrm{BIH}$ with representatives of the Chamber of Commerce, the construction industry and their sellers and distributors. A large number of interviews were conducted to avoid possible subjective assessments.

Table 6. Economy of scale/advantage of mass production.

\begin{tabular}{|c|c|c|c|}
\hline Economy of Scale/Advantage of Mass Production & $\begin{array}{l}\text { Number } \\
\text { of Points }\end{array}$ & $\begin{array}{c}\text { BAU } \\
\text { Construction }\end{array}$ & $\begin{array}{l}\text { ECO } \\
\text { Construction }\end{array}$ \\
\hline $\begin{array}{l}\text { A huge potential for price reduction on the basis of } \\
\text { mass production }\end{array}$ & 10 & & 10 \\
\hline $\begin{array}{l}\text { Significant reduction of prices, potential for mass production } \\
\text { and availability of materials on the market }\end{array}$ & 8 & & \\
\hline $\begin{array}{l}\text { Decisive reduction of prices, potential for mass production } \\
\text { and availability of materials on the market }\end{array}$ & 6 & 6 & \\
\hline Small difference in price through mass production & 4 & & \\
\hline Price remains the same, regardless of mass production & 2 & & \\
\hline Information not available & 0 & & \\
\hline
\end{tabular}

\section{(5) Durability}

Due to the long durability of natural materials, built in ECO construction, a very long durability of the whole construction, if the construction is maintained in accordance with the valid standards and regulations, is assessed. The corresponding values are given in Table 7.

Table 7. Durability.

\begin{tabular}{cccc}
\hline Durability & Number of Points & BAU Construction & ECO Construction \\
\hline$>40$ years & 10 & & 10 \\
$>30$ years & 8 & 8 & \\
$>20$ years & 6 & & \\
$>10$ years & 4 & & \\
$<10$ years & 2 & & \\
Information not available & 0 & & \\
\hline
\end{tabular}

\section{(6) Maintenance Costs}

Due to the long durability of materials in ECO construction, it is assumed, that this construction is easier and more convenient to maintain than the BAU construction. This results in a rating of 6 points for the BAU scenario and 8 points for the ECO scenario as shown in Table 8.

Table 8. Maintenance costs.

\begin{tabular}{|c|c|c|c|}
\hline Maintenance Costs & $\begin{array}{l}\text { Number } \\
\text { of Points }\end{array}$ & $\begin{array}{c}\text { BAU } \\
\text { Construction }\end{array}$ & $\begin{array}{c}\text { ECO } \\
\text { Construction }\end{array}$ \\
\hline Scarce interventions needed & 10 & & \\
\hline Small interventions needed; no skills required nor high costs & 8 & & 8 \\
\hline Medium interventions needed with medium costs & 6 & 6 & \\
\hline Often interventions needed & 4 & & \\
\hline Very demanding and highly expensive interventions needed & 2 & & \\
\hline Information not available & 0 & & \\
\hline
\end{tabular}




\section{(7) Modulation and Flexibility}

It is assumed that values of possible modulations and flexibility for both constructions are the same. As for the data in, e.g., Table 6 also this assessment is based on interviews and surveys held with representatives in $\mathrm{BiH}$. The evaluation for modulation and flexibility is shown in Table 9.

Table 9. Modulation and flexibility.

\begin{tabular}{cccc}
\hline Modulation and Flexibility & $\begin{array}{c}\text { Number } \\
\text { of Points }\end{array}$ & $\begin{array}{c}\text { BAU } \\
\text { Construction }\end{array}$ & $\begin{array}{c}\text { ECO } \\
\text { Construction }\end{array}$ \\
\hline $\begin{array}{c}\text { High level of flexibility, if a change of purpose of the building } \\
\text { is needed }\end{array}$ & 10 & 10 & 10 \\
$\begin{array}{c}\text { High level of motion } \\
\text { Medium level of modulation and flexibility, if a change of } \\
\text { purpose of the building is needed } \\
\text { Low level of modulation }\end{array}$ & 6 & \\
Low level of modulation and flexibility & 4 & \\
Information not available & 2 & \\
\hline
\end{tabular}

(8) Creation of Local Values with the Use of Local Potential and Development of Local Communities

Due to large number of elements and materials imported from abroad to develop BAU construction in $\mathrm{BiH}$, indicators' values for creating local values and potential and development of local communities differ very much from the ones in ECO construction, where the use of local natural resources and potential development of local communities is at the maximum level. The evaluation is shown in Table 10.

Table 10. Creation of local values with the use of local potential and development of local communities.

\begin{tabular}{|c|c|c|c|}
\hline Creation of Local Values with the Use of Local Capacities & $\begin{array}{l}\text { Number } \\
\text { of Points }\end{array}$ & $\begin{array}{c}\text { BAU } \\
\text { Construction }\end{array}$ & $\begin{array}{c}\text { ECO } \\
\text { Construction }\end{array}$ \\
\hline $\begin{array}{c}\text { Available in the country with local open market and a great } \\
\text { potential for mass using }\end{array}$ & 10 & & 10 \\
\hline $\begin{array}{l}\text { Available in the country with local open market and medium } \\
\text { potential for mass using }\end{array}$ & 8 & & \\
\hline Currently available, but with no commercial values & 6 & & \\
\hline A high level of import necessary & 4 & 4 & \\
\hline Not available on the local market & 2 & & \\
\hline Information not available & 0 & & \\
\hline
\end{tabular}

(9) Level of Simplicity and Costs in Cases of Connecting to Local Infrastructure and Maintenance Services

Level of simplicity and costs in cases of connecting to local infrastructures are similar for both constructions, since the technology of building is similar as demonstrated in Table 11.

Table 11. Level of simplicity and costs in cases of connecting to local infrastructure and maintenance services.

\begin{tabular}{cccc}
\hline $\begin{array}{c}\text { Level of Simplicity and Costs in Cases of Connecting to Local } \\
\text { Infrastructure and Maintenance Services }\end{array}$ & $\begin{array}{c}\text { Number } \\
\text { of Points }\end{array}$ & $\begin{array}{c}\text { BAU } \\
\text { Construction }\end{array}$ & $\begin{array}{c}\text { ECO } \\
\text { Construction }\end{array}$ \\
\hline Integrated into the building process, with any significant requests & 10 & 10 & 10 \\
Requests for connecting are minimal & 8 & & \\
Additional work and means needed & 6 & \\
Highly demanding and very expensive processes of connecting & 4 & \\
A tough process of connecting which demands changes of standards & 2 & \\
Information not available & 0 & \\
\hline
\end{tabular}


(10) Possibility for Recycling or Reusing

Value of recycling and reusing, when comparing both constructions, is much bigger in the case of ECO construction, due to the maximum use of natural materials, possessing a wide range of recycling and reusing possibilities. The associated evaluation in the form of points is shown in Table 12.

The total value of observed indicators of success for ECO construction is high, which confirms that ECO construction is available, sustainable construction for house-building (Table 13). The total result for BAU construction gives the lead to ECO construction in the value of 20.6 points, i.e., $28 \%$ of obtained values of research is lower, which represents for this construction and its development in $\mathrm{BiH}$ a great developmental challenge.

Table 12. Possibility for recycling or reusing.

\begin{tabular}{cccc}
\hline Possibility for Recycling or Reusing & $\begin{array}{c}\text { Number } \\
\text { of Points }\end{array}$ & $\begin{array}{c}\text { BAU } \\
\text { Construction }\end{array}$ & $\begin{array}{c}\text { ECO } \\
\text { Construction }\end{array}$ \\
\hline $\begin{array}{c}\text { High recycling value } \\
\text { Small requests for reconstruction }\end{array}$ & 10 & 10 \\
Medium recycling value and medium requests for reconstruction & 6 & \\
Very demanding reconstruction and a small value of reusing & 4 & 4 \\
A small recycling value & 2 & \\
Information not available & 0 & \\
\hline
\end{tabular}

Table 13. Total results.

\begin{tabular}{ccc}
\hline \multirow{2}{*}{ Total Results of Analysis } & BAU Construction & ECO Construction \\
\cline { 2 - 3 } & 74.3 & 94.9 \\
\hline
\end{tabular}

In the following table (Table 14) and written explanations are presented the final survey of challenges and indicators for the assessment of sustainability regarding the available technologies in house-building. By using a developed methodology in the presented tables, challenges and indicators are combined for reaching detailed and elaborated analysis and assessment for both constructions. Additional comparisons and analyses lead to important information on additional risks, challenges, advantages and disadvantages of these constructions.

Survey of indicators for the assessment of sustainability regarding the available technologies in house-building, given the above tables, shows many challenges in the case of BAU construction. The first of challenges is the fact that many elements of the prefabricated wall currently are not produced in $\mathrm{BiH}$ (mineral wool, oriented strand board (OSBs), plaster-cardboards, Styrofoam), but imported. This is one of the reasons why these products are more expensive, and it affects the overall higher price of the prefabricated wall. Primary energy and $\mathrm{CO}_{2}$ emission in some wall elements (Styrofoam, mineral wool, facade net) are very high, so dissipation of resources and energy occur when these materials are used. An additional impact on the price has the lack of sufficient and safe funds to support local production of some wall parts and prefabricated houses production, and as well, the market demand increase influences the price.

Quality control was established, so the needed standards are reached. Quality control of the prepared site, i.e., foundation, is an additional challenge to this kind of building.

ECO construction, i.e., the prefabricated wall using straw in its thermal-insulation material, faces a big challenge, which influences the price, in terms of sufficient and safe funds to support this production, and there is the market demand increase, too. Additionally, a big impact on the construction price can have a challenge of establishing quality control of new products. Agricultural workers, who grow crops in $\mathrm{BiH}$, until now have not had any special requests when making hay bales after the harvests, which now should be the case. It is necessary to provide education for agricultural workers and to establish quality control for making hay bales on fields. Quality control of prepared site, i.e., foundation, is an additional challenge to this kind of building. 
Table 14. Comparison of obtained indicators and challenges for BAU and ECO construction modelled after [16].

\begin{tabular}{|c|c|c|c|c|c|c|c|c|c|c|}
\hline 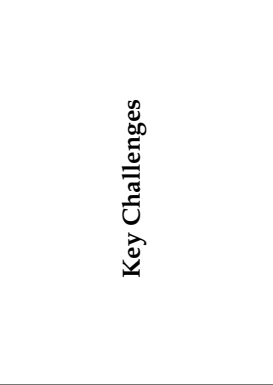 & 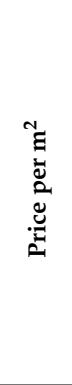 & 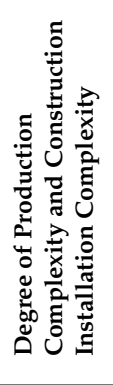 & 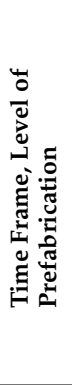 & 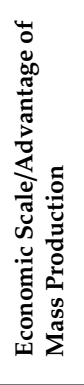 & 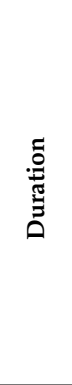 & 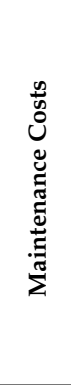 & 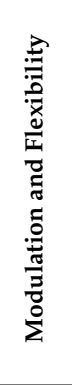 & 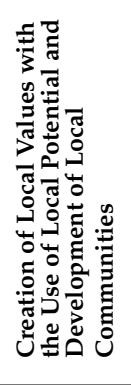 & 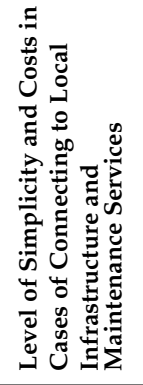 & 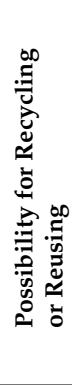 \\
\hline Lack of local resources & BAU & BAU & BAU & BAU & BAU & & & BAU & & BAU \\
\hline Lack of sufficient or & BAU & & & BAU & & & BAU & & & BAU \\
\hline safe funds & ECO & & & ECO & & & ECO & & & ECO \\
\hline $\begin{array}{l}\text { Lack of time, given the } \\
\text { urgency of requests }\end{array}$ & & & & & & & & & & BAU \\
\hline Lack of skilled labor & & & & & & & & & & BAU \\
\hline Quality control & ECO & ECO & ECO & & ECO & $\begin{array}{l}\text { BAU } \\
\text { ECO }\end{array}$ & & & & BAU \\
\hline $\begin{array}{l}\text { Dissipation due } \\
\text { to inefficiency }\end{array}$ & BAU & BAU & BAU & BAU & & & & BAU & & BAU \\
\hline $\begin{array}{l}\text { Lack of added value } \\
\text { of creativity }\end{array}$ & BAU & & $\begin{array}{l}\text { BAU } \\
\text { ECO }\end{array}$ & $\begin{array}{l}\text { BAU } \\
\text { ECO }\end{array}$ & & & $\begin{array}{l}\text { BAU } \\
\text { ECO }\end{array}$ & $\begin{array}{l}\text { BAU } \\
\text { ECO }\end{array}$ & & BAU \\
\hline Quality and location & $\begin{array}{l}\text { BAU } \\
\text { ECO }\end{array}$ & $\begin{array}{l}\text { BAU } \\
\text { ECO }\end{array}$ & $\begin{array}{l}\text { BAU } \\
\text { ECO }\end{array}$ & $\begin{array}{l}\text { BAU } \\
\text { ECO }\end{array}$ & ECO & $\begin{array}{l}\text { BAU } \\
\text { ECO }\end{array}$ & & & & BAU \\
\hline
\end{tabular}

BAU Construction - production of prefabricated walls on the basis of current technology is not demanding in terms of producing nor installing and has a long tradition in $\mathrm{BiH}$. The challenge is in a small amount of use of local resources and materials, while the most materials in the prefabricated wall are imported, which has an effect on big costs of primary energy and $\mathrm{CO}_{2}$ emission of this wall.

ECO Construction-production of prefabricated walls is part-straw, which also is not demanding in terms of production or installation. The existing production plants for prefabricated wood houses in $\mathrm{BiH}$ can redirect one part of the production process to a modular preparation, which will have different dimensions and a way of placing elements in the wall. Additional space for storing hay bales will be needed. Conditions of this space will have to be similar to the conditions of storing spaces for other thermal-insulation materials. No special safety equipment is needed for installation of these elements into the wall. The challenge will be quality controlled in the plants of both hay bales and the final process of the wall, because the system of installing is new. Since straw is the supportive element in the prefabricated wall, the dimensions of needed support, wood construction are minimal. The role of wood construction of the wall in this new technology is to form a frame, not to give any primary support.

The time to manufacture and install a prefabricated construction is minimal for both constructions.

If the complexity of building and the time needed for making and drying a classical masonry construction are compared to prefabricated wood construction, the second one has a huge advantage regarding time the needed for building and the time needed for drying, respectively.

An additional challenge posed to BAU construction lays in the time needed for procurement of material and elements, since they are not produced in $\mathrm{BiH}$ or the region. Quality control, as the biggest challenge to establishing this new technology within the production process in $\mathrm{BiH}$, will additionally impact the time of manufacturing and installing of ECO construction.

Creativity and commitment to building with local healthy materials are challenges for future architects and designers in $\mathrm{BiH}$, in regard to $\mathrm{ECO}$ construction.

Level of prefabrication of an object depends on building location. It is necessary to provide education and promotion of this kind of building at the local level through institutions of formal and non-formal education, where the optimal time for building and simplicity of it, as the advantage of this construction, will be presented. 
Combination of low purchasing power of citizens of $\mathrm{BiH}$, and people in the region, and an increased need for residential units are clear reasons for providing support to building from prefabricated elements of BAU construction, which-due to its price-remains competitive. On the other side, if all advantages of production, installation and use of ECO construction are taken into account, which also is innovative and, therefore, its mass production would bring manifold benefits at the state level, they surely justify the right to pay special attention to this construction.

A challenge regarding mass production of BAU construction is obtaining most materials and wall elements from abroad, which would lead to the economic development of other countries, but BiH. It additionally leads to dissipating value due to the inefficiency of production. Mass production would increase the number of new workplaces, but only in the primary industry, not in the adjacent sectors of civil construction.

Mass production of modern sustainable ECO construction would increase the number of new workplaces, both in primary production and its sectors, in agriculture and rural development sector.

Prefabricated objects are permanent ones, regardless of which construction is in question. Duration of these objects is determined by the maintenance level, behavior of users, quality control and quality and characteristics of building location. Duration of some wall elements should be examined and tested, in order to ensure equal duration and characteristics of the wall in the course of its whole life span, i.e., the guarantee from manufacturers, and as well, a guarantee for the whole wall should be given. In addition, in order to ensure the duration and to make easier maintenance of these objects, it is needed to determine and test which are the most suitable facades for all climate zones in BiH.

The greatest challenge in $\mathrm{BiH}$ is making a list of forest resources and sustainable forest management. For both constructions is needed to provide wood resources from the certified forests and have sustainable forest managing on the whole territory of $\mathrm{BiH}$.

Lack of sufficient and safe funds for housing issues, and a lack of local creativity and support to the prefabricated wood building are challenges posed to BAU construction. Requests are rare for addressing the issue of missing residential housing by building prefabricated wood low-energy houses. The majority of investors, who decide for the prefabricated house in $\mathrm{BiH}$, chose a classical type of building, which does not imply energy savings, because it is cheaper.

The greatest number of innovations, which ECO construction is, asks for time for support and mass application of them. Promotion of local values, health and sustainability have to be systematically prepared. Also, continuity is important for gathering as many supporters as possible, who will with their own creativity provide added value, flexibility and mass building with modern sustainable constructions. Development of production plants creates local values with maximal use of local potential and materials, which are currently ecological waste, but can be resources of sustainable economic development of rural communities of $\mathrm{BiH}$, which will bring a multitude of advantages.

Challenges for both constructions are innovations in foundation building, done in a sustainable way, which will not harm nature. Disposal of the upper layer of soil on landfills for agricultural soils, use of natural local materials which are not harmful to the environment, recycling some of the materials that are suitable for foundation building, which already is on the building sites, spatial planning and rational use of existing infrastructure would be elements of innovations in foundation building.

Impossibility to recycle or reuse the most elements of the wall is precisely the greatest environmental challenge of current prefabricated elements of BAU construction. Wood and OSBs, made of wood waste, are the only recyclable elements of the wall. Other elements of this construction cannot be recycled, or their recycling is too expensive and harmful. An additional challenge lays in researches which will address issues of modulation and flexibility of these systems in the future, which would decrease the need for recycling. A modular approach would ensure multiple uses of the wall elements, which-after dismantling — would be disposed or recycled. Lack of funds to support this phase after reconstruction or demolition is a challenge that $\mathrm{BiH}$ has to overcome.

The advantage of ECO construction is its $100 \%$ recyclability and reusability, respectively, as the most precious and the most important reasons, besides the reasons regarding the development of local 
economy, local values, turning waste into the product, opening a greater number of new workplaces, users' health and increase of life quality.

Also, this construction faces a challenge of researching for advanced systems of modulation and flexibility for the purpose of further improvement of clean innovative technologies.

(11) Concluding Remarks on Results Obtained by Method 1

The following diagram (Figure 3) is a summed survey of results obtained on the basis of the analysis of indicators for the assessment of sustainability regarding the available technologies in house-building for two elaborated constructions.

\section{Indicators for assesments of sustainability of available technology in housing building}

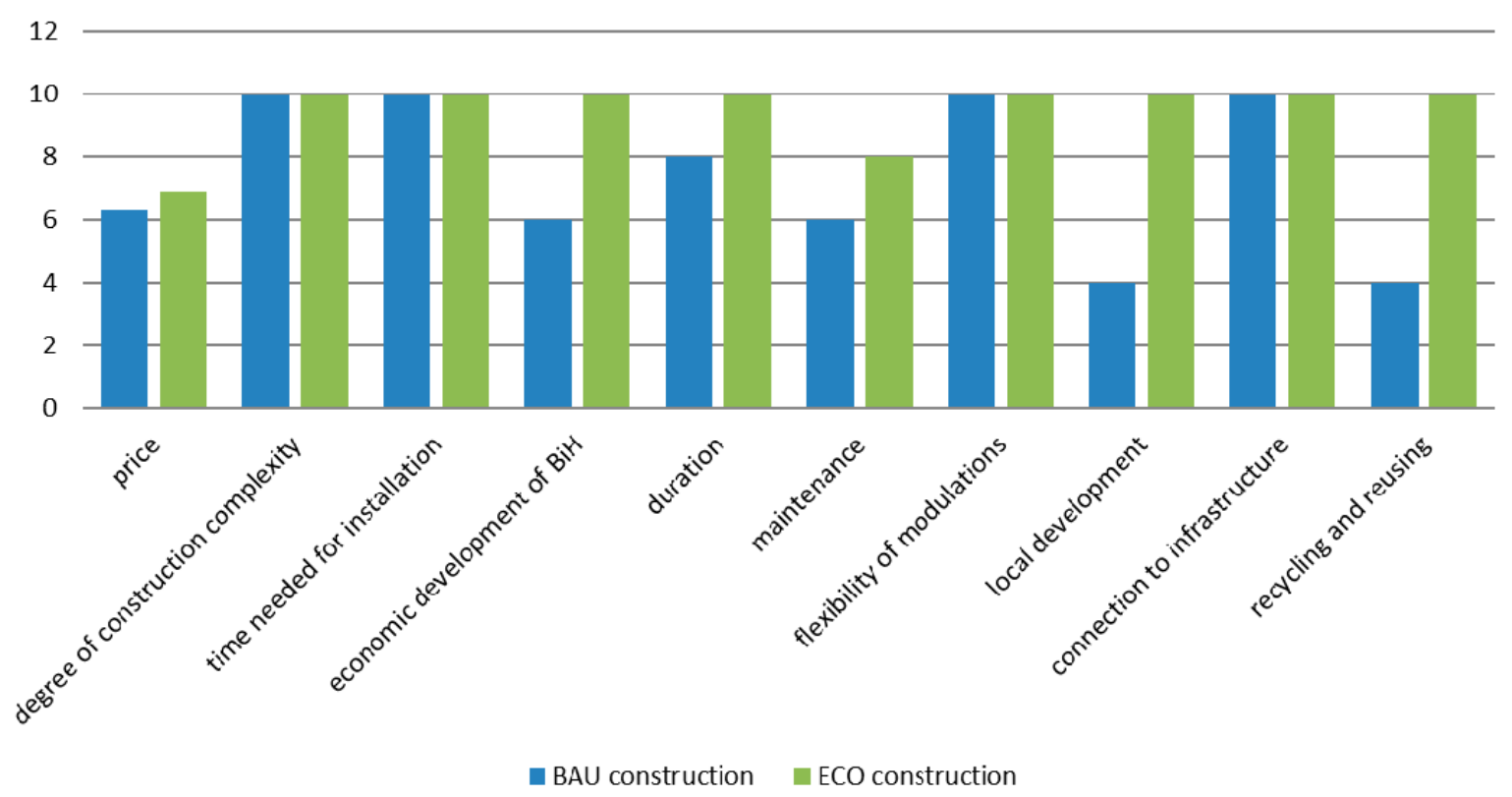

Figure 3. Diagram of the relation among values of analyzed indicators for two constructions.

On the basis of analysis and this diagram (where advantages and disadvantages of analyzed constructions are visually presented), it can be concluded that ECO construction, comparing to BAU construction, has advantages regarding the following categories: Price, opportunity for economic development of $\mathrm{BiH}$, duration, easier maintenance, opportunity for local development, and possibility of recycling of all wall parts. Regarding categories of complexity, time for installing, flexibility and modulations, and degree of easiness of connecting to the existing infrastructure, both constructions have the same values.

It can be concluded, that the analysis of indicators for the assessment of sustainability regarding the available technologies in house-building proved a great number of advantages of natural local materials. Advantage of ECO construction is in the possibility of having a lower price for objects built by this technology. Lower prices make these constructions more available to the citizens of $\mathrm{BiH}$, if they decide to build or buy residential objects. Beside the price, these constructions provide healthier residential spaces, that also have more overall quality.

Maintenance of these objects is easier, and their durability is longer due to longer durability of natural materials, used in the building process, but with an emphasis they need to be maintained in accordance with recommendations and standards of producers. A huge advantage of recycling and reusing of all parts of ECO construction is, ecologically, its greatest value what, also, to a great extent has a positive impact on providing a healthier environment in $\mathrm{BiH}$. 
For $\mathrm{BiH}$, the most significant advantage lays in possibilities of the overall sustainable economic development, especially the sustainable development of rural communities. A planned approach to economic development creates a lot of space for opening new plants, developing research centers, connecting small enterprises/producers and educating and having new workplaces that bring prosperity to $\mathrm{BiH}$.

\subsubsection{Method 2}

The second research method is based on HAM3D simulation model and calculation of environmental impact due to $\mathrm{CO}_{2}$-equivalent of the construction. HAM3D model solves numerically the equations for the combination of heat, moisture and air flow in the observed materials and constructions with the environmental conditions set, by using databases for climate zones, where the analyzed construction is placed. Due to non-existing databases for climate zones of cities in $\mathrm{BiH}$, in this case, the climate zone of the City of Vienna was used. In this research method also data from baubook [29] is used for the ecological assessment.

In order to obtain comparable the U-values of the construction a layer of sheep wool insulation was added to the ECO construction of [30]. Sheep wool has comparable characteristics concerning thermal insulation with mineral wool, but is on top of that more ecological [32,33]. Table 15 shows the results obtained by HAM3D simulation concerning the course of temperature and the total amount of water in construction. The first diagram shows the temperature on the internal side of the wall was equally stable, while U-values of the constructions are almost equal. Also, a stable amount of moisture in both constructions was reached in the second year after installing and it remained stable, i.e., after it was stabilized, there was no increase of moisture in construction. The calculation was done with real data on climate for the City of Vienna.

Figures 4 and 5 for ECO and BAU constructions show that under the influence of real data on climate, the total amount of moisture in construction becomes stable within the first two years, and afterwards stays stable - in the course of a further period of using, accumulation of moisture does not happen.

Table 15. HAM3D Results for observed constructions.

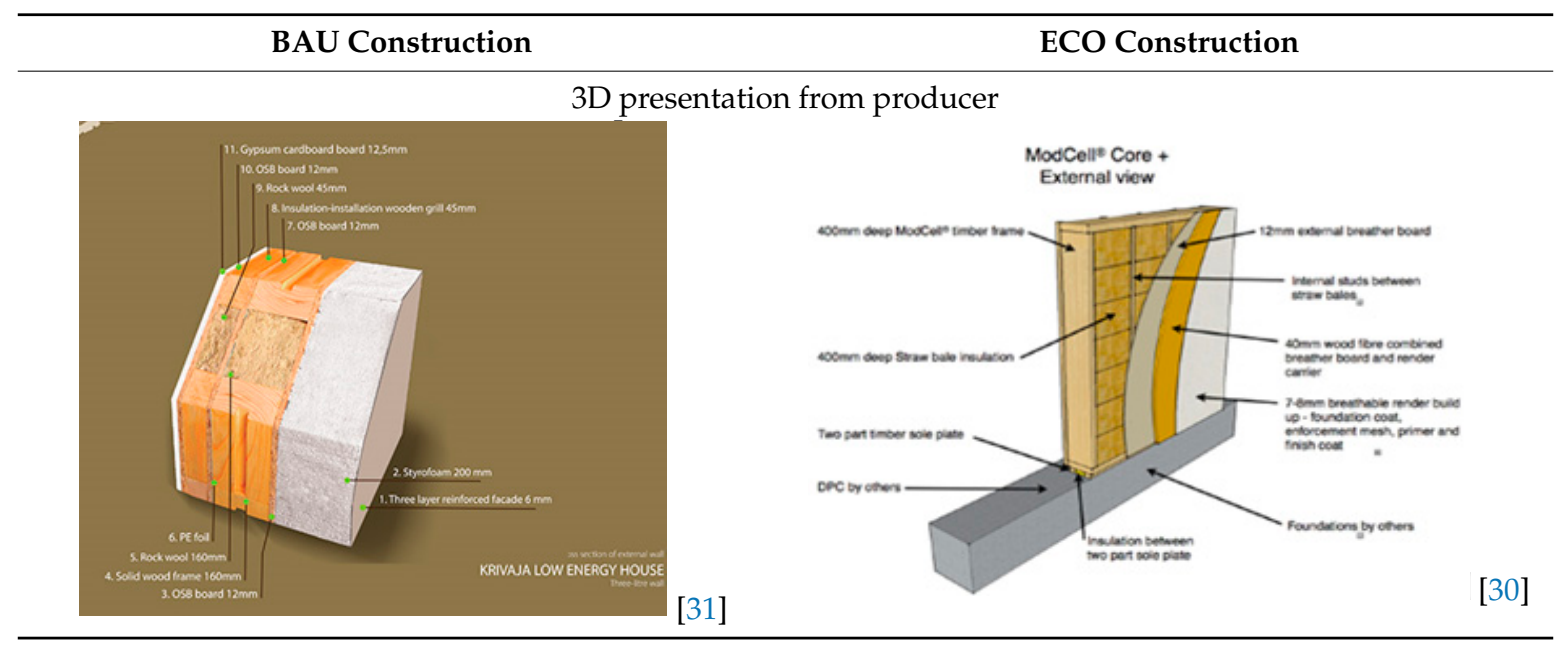


Table 15. Cont.

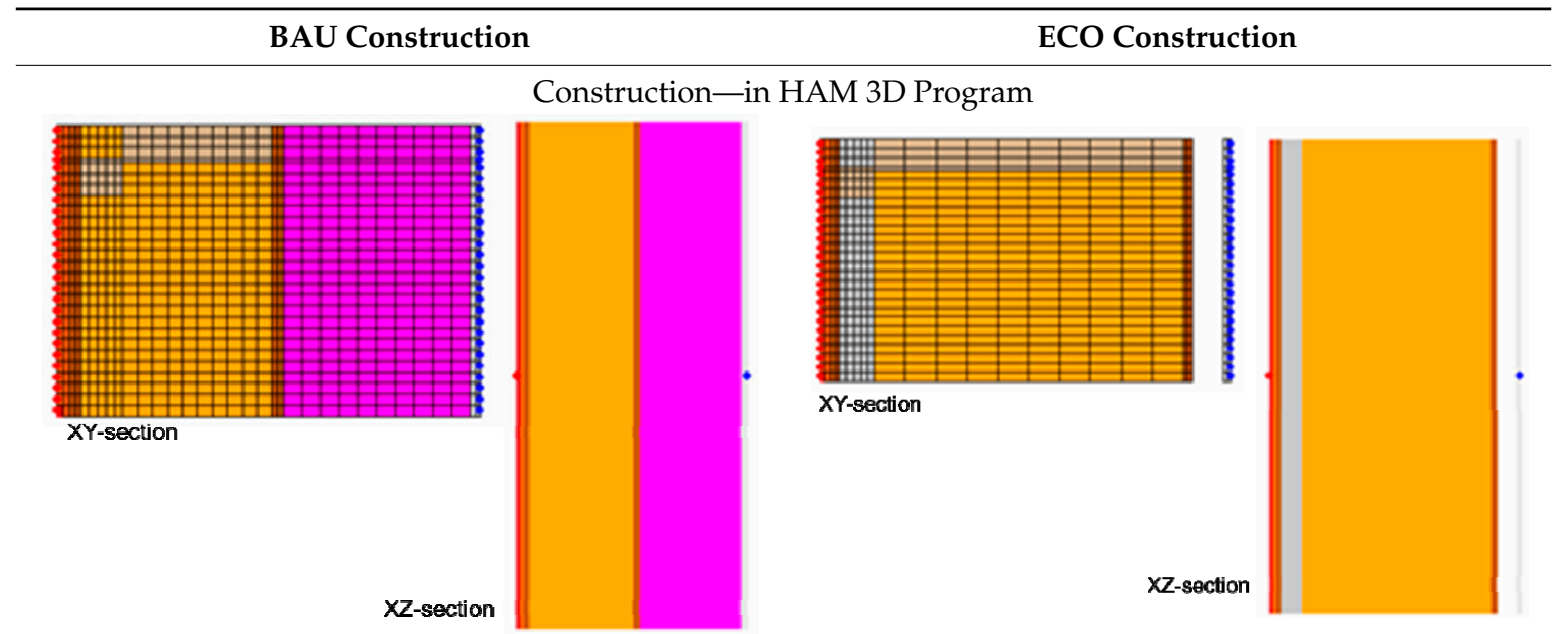

Course of temperature on the internal wall surface for five years
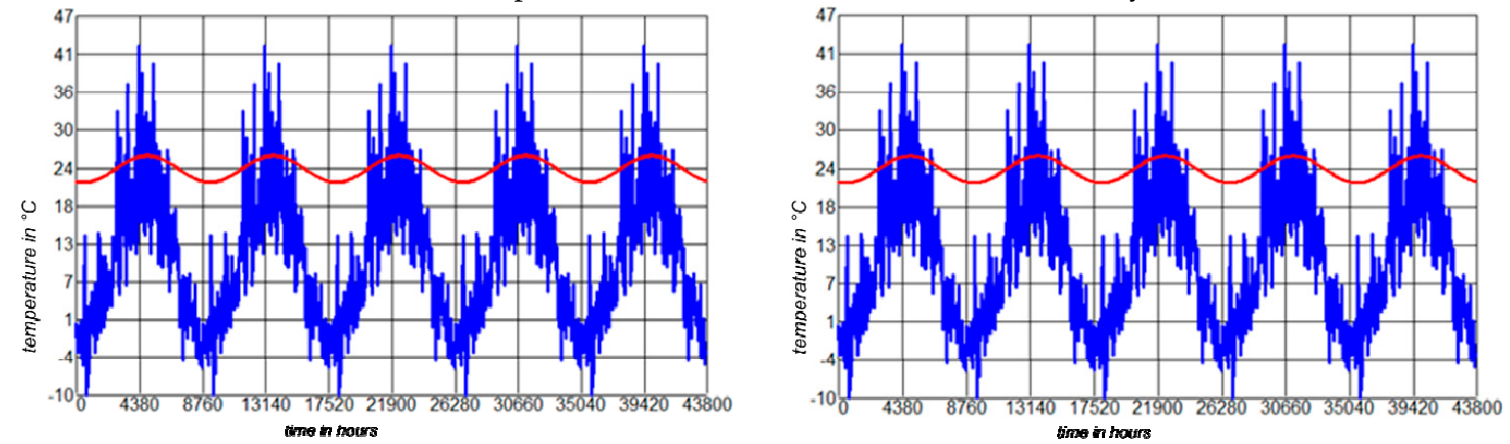

Total amount of water in construction for five years
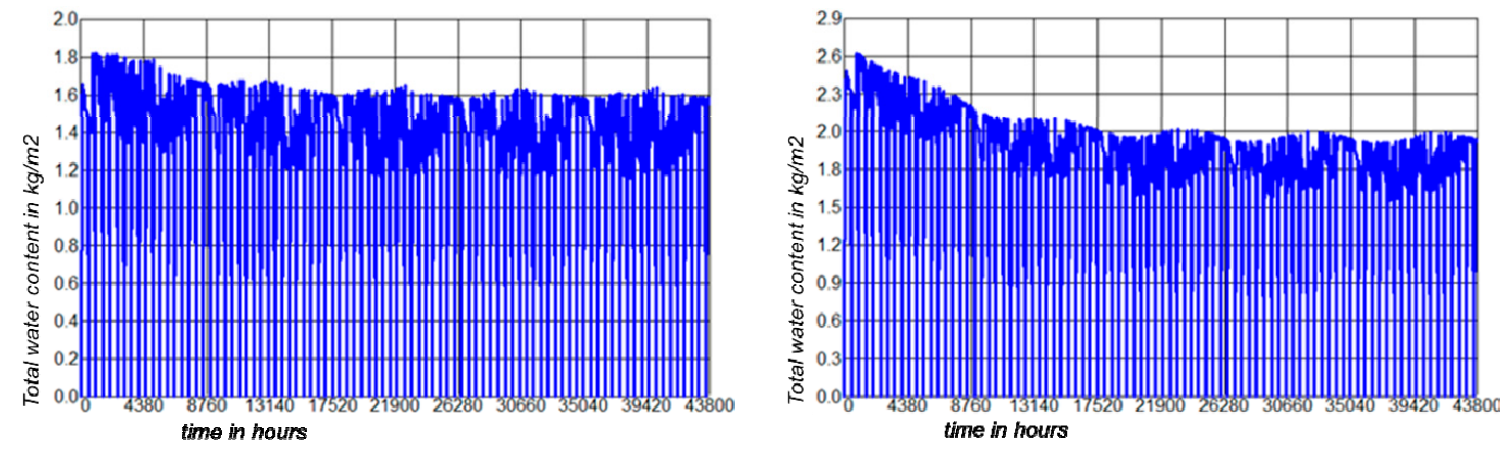

total water content for BAU construction

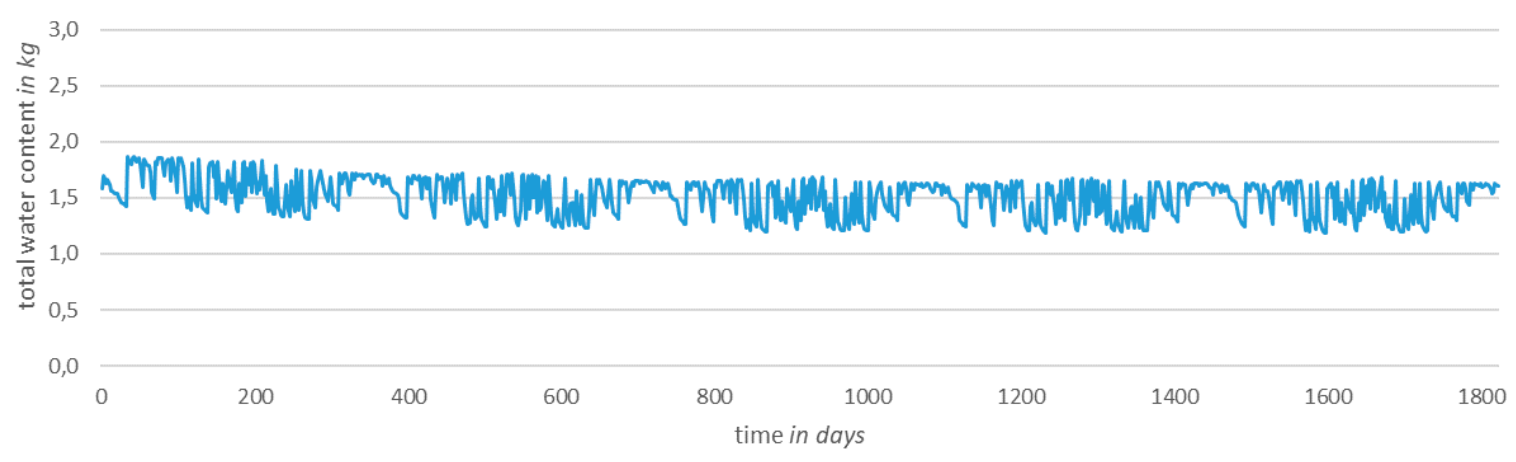

Figure 4. Singled out the result on the level of moisture for BAU construction according to HAM 3D calculations during the first five years. 
total water content for ECO construction

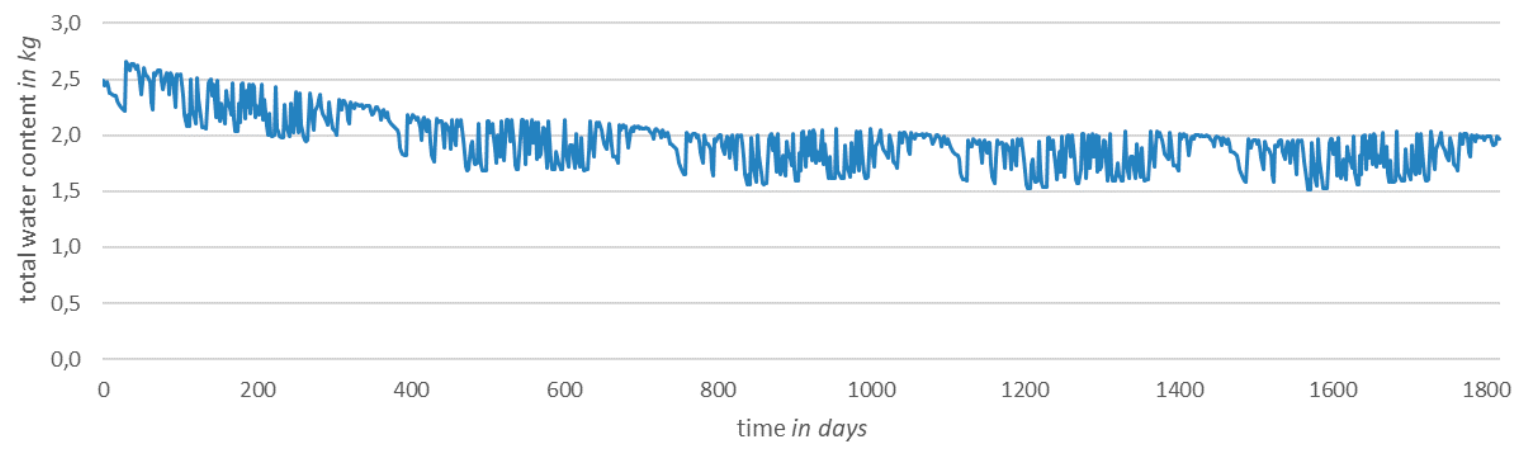

Figure 5. Singled out the result on the level of moisture for ECO construction according to HAM 3D calculations during the first five years.

Results obtained from calculations for eco balance and a survey of relations between materials, on the one side, and on the other, the whole construction, with consideration of global warming, the equivalent of $\mathrm{CO}_{2}$ emission and acidity of constructions, which were researched here, are shown in Tables 16 and 17. It has to be emphasized that conventional vapor barriers for both constructions are omitted, because materials for these barriers are artificial and not convenient for combining with natural materials. There is a vapor barrier made of cellulose, used in prefabricated wood constructions, in combination with natural materials (sheep wool and straw), that has good results and allows natural materials to breathe. Since a primary objective was not to research a motion of moisture in construction, a vapor barrier was left out from both analyzed constructions.

The U-values for both constructions were checked, as shown in Tables 16 and 17. Values for both constructions are in the range of values for passive houses.

Table 16. U-values and eco balance-BAU Construction.

\begin{tabular}{|c|c|c|c|c|c|c|}
\hline \multirow{2}{*}{ Prefabricated External Wall of Wood BAU } & d & $\lambda$ & $\mu$ & $\rho$ & GWP & AP \\
\hline & [m] & {$[\mathrm{mK} / \mathrm{W}]$} & [1] & {$\left[\mathrm{kg} / \mathrm{m}^{3}\right]$} & {$\left[\mathrm{kg} \mathrm{CO}_{2}\right]$} & {$\left[\mathrm{kg} \mathrm{SO}{ }_{2}\right]$} \\
\hline Epoxy resin plaster & 0.020 & 0.70 & 50 & 1000 & 4.92 & 0.0294 \\
\hline Net for facade & 0.001 & 0.20 & 1 & 1000 & 2.45 & 0.0164 \\
\hline Styrofoam & 0.200 & 0.04 & 60 & 25 & 20.85 & 0.0745 \\
\hline Wood construction $(10 \%)$ & 0.160 & 0.12 & 50 & 450 & -9.07 & 2.4552 \\
\hline Mineral wool & 0.160 & 0.04 & 1 & 150 & 34.56 & 0.2472 \\
\hline OSB & 0.012 & 0.13 & 200 & 610 & -7.32 & 0.0441 \\
\hline Mineral wool & 0.045 & 0.04 & 1 & 150 & 9.72 & 0.0695 \\
\hline OSB & 0.012 & 0.13 & 200 & 610 & -7.32 & 0.0441 \\
\hline Plaster-cardboard & 0.015 & 0.21 & 1 & 850 & 2.66 & 0.0089 \\
\hline Rsi+Rse & 0.17 & {$\left[\mathrm{~m}^{2} \mathrm{~K} / \mathrm{W}\right]$} & & & & \\
\hline $\mathrm{R}^{\prime} \mathrm{T}$ & 9.93 & $\mathrm{~m}^{2} \mathrm{~K} / \mathrm{W}$ & & & & \\
\hline $\mathrm{R}^{\prime \prime} \mathrm{T}$ & 9.61 & $\mathrm{~m}^{2} \mathrm{~K} / \mathrm{W}$ & & & & \\
\hline U-value & 0.10 & $\mathrm{~W} / \mathrm{m}^{2} \mathrm{~K}$ & & & & \\
\hline
\end{tabular}


Table 17. U-values and eco balance-ECO Construction.

\begin{tabular}{|c|c|c|c|c|c|c|}
\hline \multirow{2}{*}{ Prefabricated External Wall of Wood ECO } & d & $\lambda$ & $\mu$ & $\rho$ & GWP & AP \\
\hline & [m] & {$[\mathrm{mK} / \mathrm{W}]$} & [1] & {$\left[\mathrm{kg} / \mathrm{m}^{3}\right]$} & {$\left[\mathrm{kg} \mathrm{CO}_{2}\right]$} & {$\left[\mathrm{kg} \mathrm{SO}_{2}\right]$} \\
\hline Epoxy resin plaster & 0.020 & 0.700 & 50 & 1000 & 4.92 & 0.0294 \\
\hline Net for facade & 0.001 & 0.200 & 1 & 1000 & 2.45 & 0.0164 \\
\hline Insulation of wood fibres & 0.060 & 0.051 & 5 & 160 & -1.76 & 0.0384 \\
\hline Wood construction $(10 \%)$ & 0.420 & 0.120 & 50 & 450 & -23.81 & 0.6445 \\
\hline Straw & 0.420 & 0.051 & 1 & 120 & -56.70 & 0.0386 \\
\hline OSB & 0.012 & 0.130 & 200 & 610 & -7.32 & 0.0441 \\
\hline Sheep wool & 0.045 & 0.040 & 1 & 19 & 0.40 & 0.0077 \\
\hline Plaster-cardboard & 0.015 & 0.210 & 1 & 850 & 2.66 & 0.0089 \\
\hline Rsi+Rse & 0.17 & {$\left[\mathrm{~m}^{2} \mathrm{~K} / \mathrm{W}\right]$} & & & & \\
\hline $\mathrm{R}^{\prime} \mathrm{T}$ & 10.15 & $\mathrm{~m}^{2} \mathrm{~K} / \mathrm{W}$ & & & & \\
\hline $\mathrm{R}^{\prime \prime} \mathrm{T}$ & 7.59 & $\mathrm{~m}^{2} \mathrm{~K} / \mathrm{W}$ & & & & \\
\hline U-value & 0.11 & $W / m^{2} K$ & & & & \\
\hline
\end{tabular}

If only values of global warming potential and $\mathrm{CO}_{2}$ emission are compared, obtained results clearly point to the advantages of natural materials, which have a minimal influence on the environment in their life cycle.

In the example for BAU construction (Figure 6) can be clearly seen to what extent the impact on the environment is negative and how high is the global warming potential of materials as Styrofoam and PVC net for the facade, and also, of mineral wool. All mentioned materials are imported in $\mathrm{BiH}$, which additionally enlarges their negative impact on the environment, due to the calculation of $\mathrm{CO}_{2}$ emission in the course of their transport to the location of installing.

In the example of ECO construction (Figure 7) can be immediately seen to what extent natural materials have an advantage over artificial ones. Some natural materials neutralize global warming effects and $\mathrm{CO}_{2}$ emission due to their natural ability to accumulate $\mathrm{CO}_{2}$, and that is the reason why values of impact on the environment and global warming potential are negative. Therefore, Figure 7 strongly supports the development of clean technologies in $\mathrm{BiH}$, which would locally produce all parts of prefabricated houses.

\section{Equivalent of $\mathrm{CO}_{2}$ for $\mathrm{BAU}$ construction}

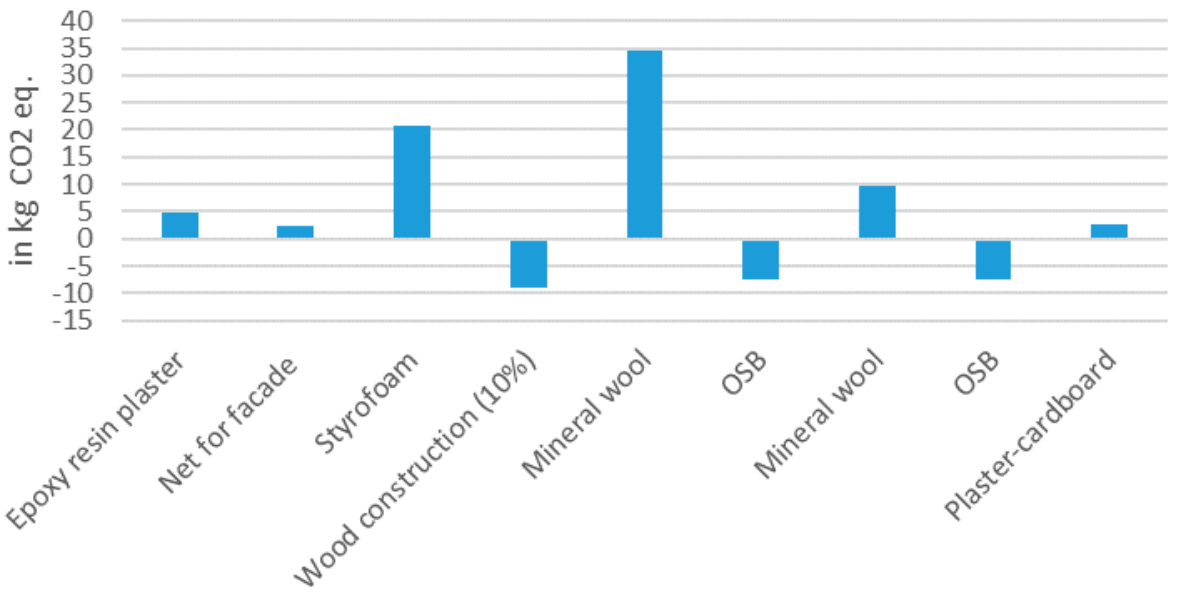

Figure 6. Potential of global warming-BAU Construction. 


\section{Equivalent of $\mathrm{CO}_{2}$ for $\mathrm{ECO}$ construction}

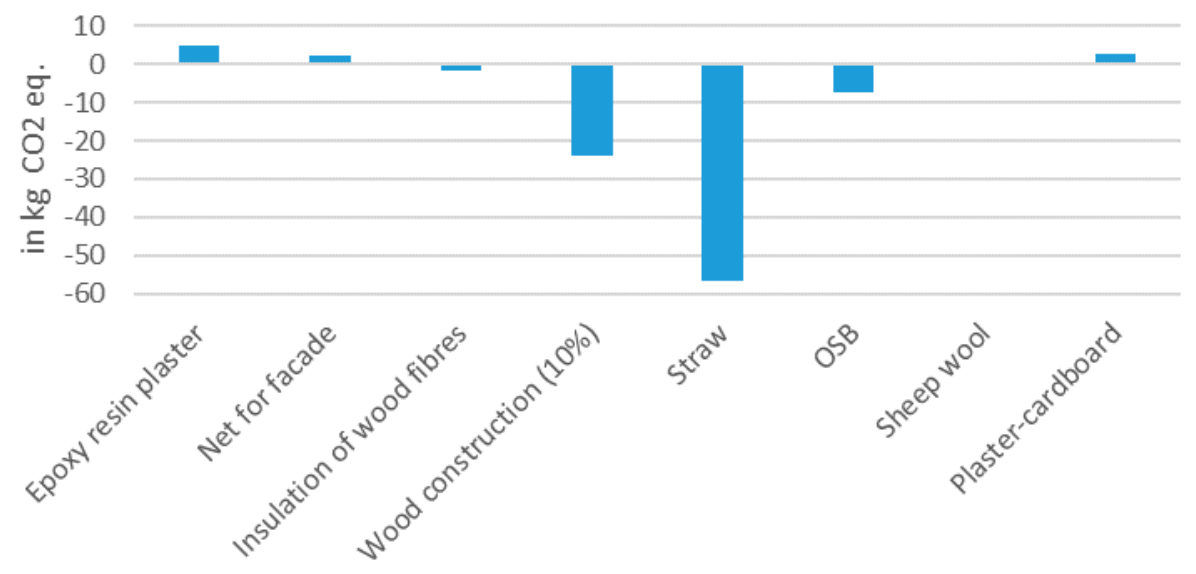

Figure 7. Potential of global warming-ECO Construction.

\section{Conclusions}

From all the mentioned above, that resulted out of the conducted research, a conclusion imposes itself that the use of natural materials in the clean technologies of prefabricated constructions for house-building brings multiple benefits, not only for the development of $\mathrm{BiH}$, but worldwide. The same, further, reflects in the wide spectrum of advantages, as are new workplaces and a decrease of harmful impact on the environment.

A special emphasis should be placed on the advantage relating to the economic development of $\mathrm{BiH}$, that would come after the introduction of new clean technologies. New technology development in BiH would surely lead to building new, or adapting old plants, and making connections among these plants for the purpose of production of final products, as are prefabricated constructions of natural materials. Additionally, all accompanying services would be created as a result of developments of forest management and agricultural management, as well as the development of rural communities and the services within them. It is especially important, that the issues regarding ecological waste would be solved. Therefore, the use of the potential of natural materials would not only have a high impact on the construction sector, but also improve diversification and protection of biodiversity in other sectors.

Due attention should be paid to needs for new workplaces in the primary plants and accompanying service in both the civil construction industry and accompanying industries that manage natural materials. An increased employment rate would lead to more adequate filling the budget on all levels, especially pension and health care funds.

A special focus has to be put on a great need of having a unique database for the whole $\mathrm{BiH}$, containing climate data necessary for future calculations of optimal solutions for small local areas. Statistical climate data for every location will contribute to the optimization of future solutions, which is a task of future researches. Furthermore, for researching or certifying buildings, it is necessary to define and adopt databases on climate conditions for the last one hundred years for the whole territory of the state, and on the basis of data gathered from meteorological stations in $\mathrm{BiH}$.

Mass use and acceptance of innovative technologies demand time; therefore, full support for the introduction of innovative clean technologies, provided by the state of $\mathrm{BiH}$, is required. Above all, it's important to involve all stakeholders in an interdisciplinary approach for solving challenges in the civil construction sector.

There is a risk for investors in cases of decision-making regarding investments in clean innovative technologies, because there is no support in $\mathrm{BiH}$ for such investments. However, if the government of $\mathrm{BiH}$ would support an initiative in regard to exemption of relevant taxes, i.e., "Green" tax relief initiative, and, additionally, if it would allocate support funds for clean technologies development, 
investors would be encouraged by these and similar reliefs to making the mentioned investments and chose development. It would be important to secure subsidies or package of incentives, as an additional stimulus, for ecologically aware investors, who decide to use new technologies in the building process. In this context, it would be especially important to ensure support of the government of $\mathrm{BiH}$ for education and research institutions and for promotion of this kind of building.

In line with this, the government of $\mathrm{BiH}$, by providing its support to formal and non-formal targeted education, implemented on all levels and offered to all key stakeholders, would accomplish multiple benefits for citizens, civil construction industry, accompanying civil construction sectors, educational and research institutions and their mutual networking.

Keeping a balance between advantages and disadvantages, risks and gains, opens a great space for a positive discussion on future strategic commitments of the state $\mathrm{BiH}$ in the housing sector. Additional positive discussions and researches would enable optimal use of advantages, that would be brought by the application of clean sustainable technologies, based on natural resources, to the overall development of $\mathrm{BiH}$. Therefore, it is surely possible to reach the best strategic goals of sustainable development of $\mathrm{BiH}$ by an integral interdisciplinary approach and involvement of all stakeholders.

Author Contributions: Data curation, S.K. and J.H.; Investigation, S.K., A.K. and J.H.; Methodology, S.K., A.K. and J.H.; Supervision, A.K.; Validation, S.K. and A.K.; Visualization, S.K. and J.H.; Writing-original draft, S.K. and J.H.; Writing-review \& editing, A.K. and L.S.

Funding: This research was funded by the TU Vienna International Office.

Acknowledgments: The authors acknowledge the TU Wien University Library for financial support through its Open Access Funding Program.

Conflicts of Interest: The authors declare no conflict of interest.

\section{References}

1. Eurostat. Air Emissions Accounts. Available online: https://ec.europa.eu/eurostat/web/environment/ emissions-of-greenhouse-gases-and-air-pollutants/air-emissions-accounts (accessed on 8 May 2014).

2. König, H. Wege zum Gesunden Bauen, 9th ed.; ökobuch Verlag: Staufen bei Freiburg, Germany, 1997.

3. European Commission. Agriculture and Rural Development Budget. Available online: https://ec.europa.eu/ agriculture/cap-funding/budget_en (accessed on 8 May 2014).

4. Agencija za statistiku Bosnia and Herzegovina. Unutrašnje Migracije U Bosni I Hercegovini Za 2012. Available online: http://www.bhas.ba/saopstenja/2013/DEM_2012_001_01_bos.pdf (accessed on 8 May 2014).

5. Official Web of Ministry for Foreign Affairs and Economic Relations BiH. Available online: http://www. mvteo.gov.ba/data/Home/Dokumenti/Poljoprivreda/BOS_SPRR_2018--2021_-_korekcija.pdf (accessed on 23 May 2019).

6. Schoof, A.; Korjenic, A. Ökologische und ökonomische Gebäudebewertung für ein Einfamilienhaus in Varianten. Bauphysik 2015, 38, 88-97. [CrossRef]

7. The Foreign Trade Chamber of BiH. Official website of the Foreign Trade Chamber of BiH.; Export Strategy for Civil Construction Sector. Available online: www.komorabih.ba (accessed on 2 September 2013).

8. Salman, M. Sustainability and Vernacular Architecture: Rethinking What Identity Is; IntechOpen: London, UK, 2018.

9. König, H.; Kohler, N.; Kreißig, J.; Lützkendorf, T. Lebenszyklusanalyse in der Gebäudeplanung, 1st ed.; Institut für internationale Architektur-Dokumentation GmbH \& Co. KG: Regensburg, Germany, 2009.

10. Zhang, P.Q.; Wang, Y. Research on green building design based on ecological concept. MATEC Web. Conf. 2016, 63, 02040. [CrossRef]

11. Torring, T.; Sandvik, K. Management of demolition waste-using life cycle assessment methodologies. In Proceedings of the International Symposium of Integrated Life-Cycle Design of Materials and Structures, Helsinki, Finland, 22-24 May 2000; pp. 522-526.

12. Vakili-Ardebili, A.; Boussabaine, A.H. Ecological building design determinants. Archit. Eng. Des. Manag. 2010, 6, 111-131. [CrossRef] 
13. Obućina, M.; Kuzman, M.K.; Sandbeg, D. Use of Sustainable Wood Building Materials in Bosnia and Herzegovina, Slovenia and Sweden; University of SarajevoMechanical Engineering FacultyDepartment Wood Technology: Obala, Sarajevo, 2017; p. 216.

14. Korjenic, A.; Klarić, S. The revival of the traditional Bosnian wood dwellings. Energy Effic. 2011, 4, 547-558. [CrossRef]

15. Abschlussbericht der Brundtland-Kommission der UN (United Nations). Our Common Future; Oxford University Press: Oxford, UK, 1987.

16. Srpske, V.R.; Luka, B.; Luka, B. Ruralna Politika Evropske Unije-Iskustva I Pouke Za Bosnu I Hercegovinu Rural Policy of the European Union-Experiences and Lessons. Economics 2016, 4, 73-88.

17. Häkkinen, T. Assessment of indicators for sustainable urban construction. Civ. Eng. Environ. Syst. 2007, 24, 247-259. [CrossRef]

18. Hegner, H.D. Nachhaltiges Bauen in Deutschland-Bewertungssystem des Bundes für Büro- und Verwaltungsbauten. Stahlbau 2010, 79, 407-417. [CrossRef]

19. Milutinovic, S.; Zivkovic, S. Planning local sustainable development in Western Balkans. Manag. Environ. Qual. Int. J. 2014, 25, 19-29. [CrossRef]

20. Passer, A.; Wall, J.; Kreiner, H.; Maydl, P.; Höfler, K. Sustainable buildings, construction products and technologies: Linking research and construction practice. Int. J. Life Cycle Assess. 2015, 20, 1-8. [CrossRef]

21. Krasny, E.; Klarić, S.; Korjenić, A. Analysis and comparison of environmental impacts and cost of bio-based house versus concrete house. J. Clean. Prod. 2017, 161, 968-976. [CrossRef]

22. Cologne Institute for Economy Research. Wertschöpfungskette Bau. Analyse der volkswirtschaftlichen Bedeutung der Wertschöpfungskette Bau. Forschungsvorhaben 10.08.17.7-07.23. Endbericht für das Bundesamt für Bauwesen und Raumordnung.no. August 2008, p. 110. Available online: http://www.irbnet. de/daten/baufo/20088034355/Endbericht.pdf (accessed on 26 March 2019).

23. Vrijhoef, R.; Koskela, L. The four roles of supply chain management in construction. Eur. J. Purch. Suppl. Manag. 2000, 6, 169-178. [CrossRef]

24. Magwood, C.; Mack, P.; Therrien, T. More Straw Bale Building: How to Plan, Design and Build with Straw; New Society Publisher: Gabriola Island, BC, Canada, 2005.

25. Wallbaum, H.; Ostermeyer, Y.; Salzer, C.; Escamilla, E.Z. Indicator based sustainability assessment tool for affordable housing construction technologies. Ecol. Indic. 2012, 18, 353-364. [CrossRef]

26. Spoljnotrgovinska komora BiH; Vanjskotrgovinske komore BiH. Izvozna strategija za sektor građevinarstva, Vanjskotrgovinska. Available online: www.komorabih.ba (accessed on 2 September 2013).

27. Cinelli, M.; Coles, S.R.; Kirwan, K. Analysis of the potentials of multi criteria decision analysis methods to conduct sustainability assessment. Ecol. Indic. 2014, 46, 138-148. [CrossRef]

28. Fond KS za izgradnju stanova, Fond Kantona Sarajevo za Izgradnju Stanova. Available online: https: //www.fondstan.ba/kontakt.php (accessed on 24 May 2019).

29. Baubook GmbH. baubook: Ökologische Baustoffe. 2017. Available online: https://www.baubook.info (accessed on 1 November 2017).

30. ModCell Factory. Available online: http://www.modcell.com (accessed on 20 July 2013).

31. Krivaja-TMK doo, Krivaja Homes. Available online: http://www.krivajahomes.com (accessed on 20 July 2013).

32. Zach, J.; Korjenic, A.; Petránek, V.; Hroudová, J.; Bednar, T. Performance evaluation and research of alternative thermal insulations based on sheep wool. Energy Build. 2012, 49, 246-253. [CrossRef]

33. Korjenic, A.; Klaric, S.; Hadžic, A.; Korjenic, S. Sheep wool as a construction material for energy efficiency improvement. Energies 2015, 8, 5765-5781. [CrossRef]

(C) 2019 by the authors. Licensee MDPI, Basel, Switzerland. This article is an open access article distributed under the terms and conditions of the Creative Commons Attribution (CC BY) license (http://creativecommons.org/licenses/by/4.0/). 